\title{
Acceleration in the Building Floors Using the Seismo-Geodynamic Theory
}

\author{
L. Zeevaert-Wiechers \\ División de Estudios de Posgrado \\ Faculatd de Ingeniería, UNAM
}

(Recibido:mayo de 2002; aceptado: octubre de 2003)

\begin{abstract}
Theex peri encehas in di cated theim por tancein the seis mic behavior of build ings and in thestructural prob lems taking placein theup per floors of tall build ings, dur ing destructiveearth quakes. Thein ter est has aroused in the ap pli ca tion of the "Seismo geodynamics Theory" to solvethe seis mic prob lems of the sub soil and foun da tions, and themethod to cal cu latetheac cel er a tion in thefloors of buildingsbecause of theseis mic ef fect of theverti cal and hor i zon tal ro ta tion sof thefoun da tion, and to ver ify if the structure of thebuild ing can takesafetheseis mic forces. An im por tant seis micob ser va tion was made by the au thor in 1962, from the recorded seudo-acceleration responsespectrums, ob tained at theground surface of the $\mathrm{C}$ en tral Park and those ob tained at the base of the rigid foun da tion of the Tower Latino A mericana in $\mathrm{M}$ ex ico City. The au thor found that the ra tio of the ac cel er a tions for $10.0 \%$ critical damp ing between thesetwo places, less than onehun dred meters appart, showed that the rigid box type foun da tion of the "Tower La tino" suf fered only on theor der of $50 \%$ to $60 \%$ of theac cel er a t ion with respect tothespectral accel er a tion at theground sur facein the $C$ en tral Park. Theaboveobservation was ver ified theoreti cally by theau thor.
\end{abstract}

Keywords: Seismo-geodynamics, ap plication, sub soil, foun da tion, build ing floors.

\section{Resumen}

La experiencia ha indicado la importancia que tiene el comportamiento sísmico de los edificios y los problemas estructurales que se ocasionan en los pisos altos durante sismos destructivos. Se ha despertado interés en la aplicación de la "Teoría de la sismo-geodinámica" para resolver problemas sísmicos del subsuelo y cimentaciones, además del método para calcular la aceleración en los pisos de los edificios, debido a la acción sísmica que produce la rotación vertical y horizontal de la cimentación, y así verificar si la estructura del edificio puede tomar con seguridad las fuerzas sísmicas. Una observación importante fue hecha por el autor en el año de 1962, en registros de los espectros de respuesta de seudo-aceleración, obtenidos en la superficie del suelo en la "Alameda Central" y los obtenidos en la base de la cimentación rígida de la Torre Latino Americana en la Ciudad de México. El autor encontró que la relación de las aceleraciones para el $10.0 \%$ de amortiguamiento crítico entre estos dos lugares distanciados menos de 100 metros, mostraron que la cimentación rígida de tipo cajón de la "Torre Latino" sufrió solo del orden de $50 \%$ a $60 \%$, con respecto a la aceleración correspondiente a la superficie de la "Alameda Central". La observación descrita fue verificada teóricamente por el autor.

Descriptores: Sismo-geodinámica, aplicación, subsuelo, cimentación, pisos de los edificios. 


\section{Introduction}

Be cause of the in ter est that has aroused in the ap plication of the Seismo-Geodynamics theory to solve seis mic prob lems in the sub soil and foun da tions, the au thor has re vised and en larged the origi nal ver sion of this work "Sgedfalt" pub lished in de cem ber 1999, now the au thor pres ents here again the method to cal culate the ac cel eration in the flo ors of build ings by means of the seismo-dynamic the ory.

It is very im por tant to foresse the dy namic force to which the ob jects on the floors of build ings may be subjected and to verify if the structure of the build ing can take the seis mic forces.

The experience has in di cated the im portance in the seismic behavior of buildings, and the structural prob lems in the upper floors of tall build ings, durung de struc tive earth quakes. The ac cel er a tion in the top floors is much higher than the ac cel er ation assigned at the ground surface, "Because of the ef fect of the ver ti cal and hor izon tal seis mic rota tions of the fo un da tion".

Knowing the acceleration to each floor of the building and the individual mass of the objects. The seis mic force in each one of them may be calculated by means of the following dynamic law Force $=$ Mass $\times$ Ac cel er a tion, (New ton), thus being able to fix on the floor the objects with sufficient strength to avoid displacement or overturning. In the same way knowing the acceleration and the floor mass, the dynamic force act ing in each floor level can be calculated and the structural resistance and lat eral dis place ments ver i fied.

Fur ther more, the knowl edge of the rel a tive displacement between the floors are requiered to fore see the gap to be given in the con struc tion to the float ing walls, win dows and stair ways be tween floors, and to take into account the dynamic distortion induced in them as well as in other arhitectonic elements.

An importantseismic observation was made by the au thor in 1962, from the re corded seudoac cel er a tion re sponse spec trums, ob tained at the ground sur face at the Alameda Cen tral and those ob tained at the base of the rigid foun da tion of the Tower La tino Americana in Mex ico City (Fig ure 1).
Notice in figure 1, that the ratio of the accelerations for $5.0 \%$ crit i cal damp ing be tween these two places, one hundred meters appart, show at the rigid box type foundation of the L.A. Tower to a total depth of 16 me ters of the "Sheet Piles", that the L.A. Tower shows only on the order of $50 \%$ seudo-acceleration with respect to the spectral acceleration at the ground sur face in the Alameda Park (Fig ure 1).

Theabove ob servation was verified the o retically by the author, by means of an analysis he developed and named "The Seismo-Geodynamic Theory", using the soil dynamics physicalinformation of the site. The result of the calculation is shown in fig ure 2 . Where the stra tig ra phy of the sub soil is reported, also the quantitative dynamic pa rameters corresponding to the site in ques tion.

The analysis in numerical and graphical form shows that the acceleration at the depth of the foundation grade el e va tion is on the order of $59 \%$ of the value given by the response acceleration spectrum at the ground surface, hence, the theoreticalcalculation is co in ci dent with the re sponse of the ac cel er a tion spec trums, shown in figure1.

The phe nom e non herein re ported has been observed in other places. There fore, the con clu sion is that the ac cel er a tion im posed to the build ings cor respond to that one the seismic wave induces at the foundation grade elevation. Therefore this value is a func tion of the foun da tion depth.

On acount of this unexpected important seismic phenomenon, the author was motivated to continue investigating the seismic effects in buildings and other seismic problems of ground displacements, distortions. Stresses and accelerations, that is to improve as much as possible the practical use of "The Seismo-Geodynamic Theory". 

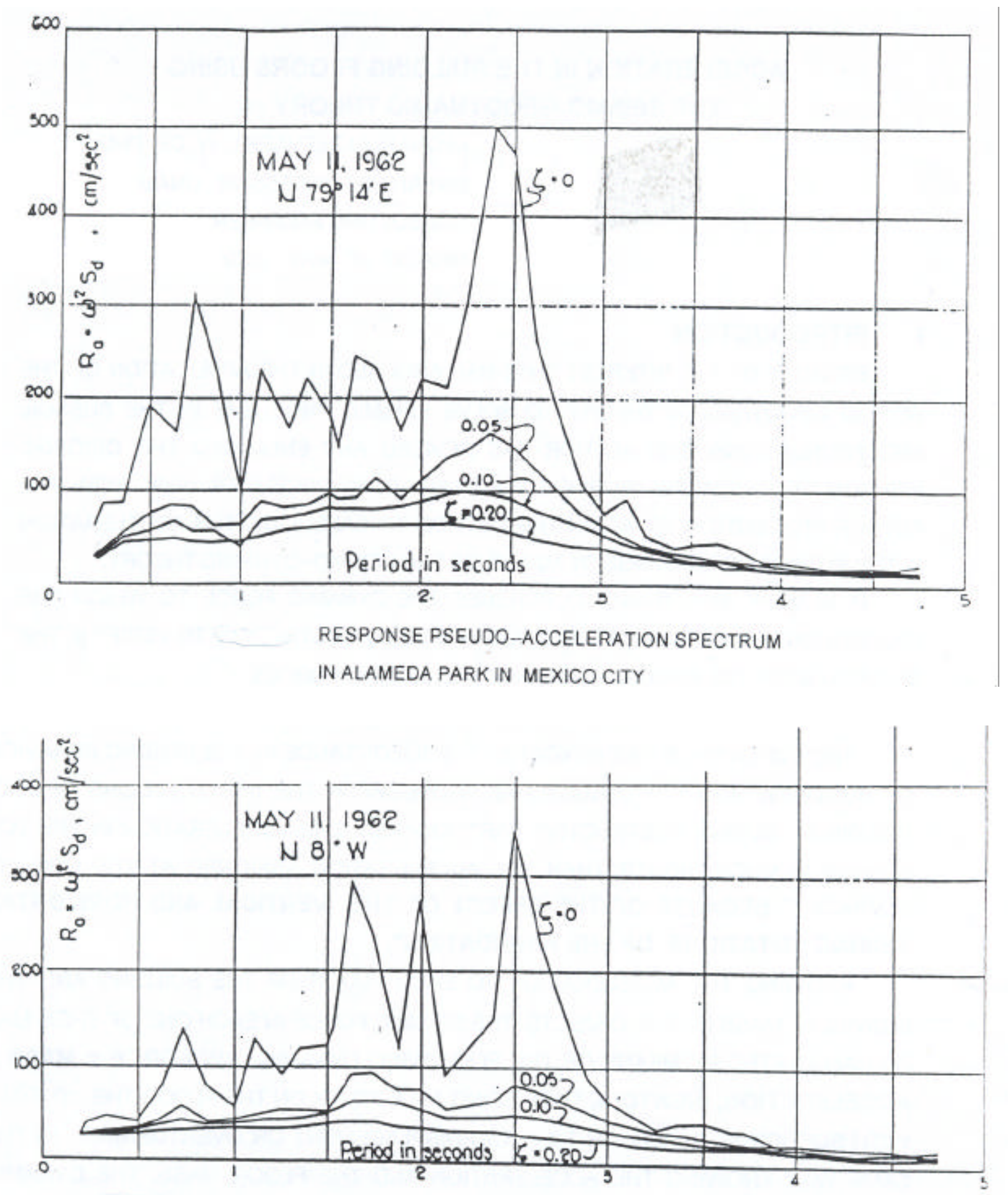

RESPONSE PSEUDO--ACCELERATION SPECTRUM IN THE FOUNDATION BASE OF THE LATINO AMERICANA TOWER IN MEXICO, CITY.

Figure 1. Response Pseudo-Acceleration Spec trums (9) (Zeevaert, 1972-1982) 


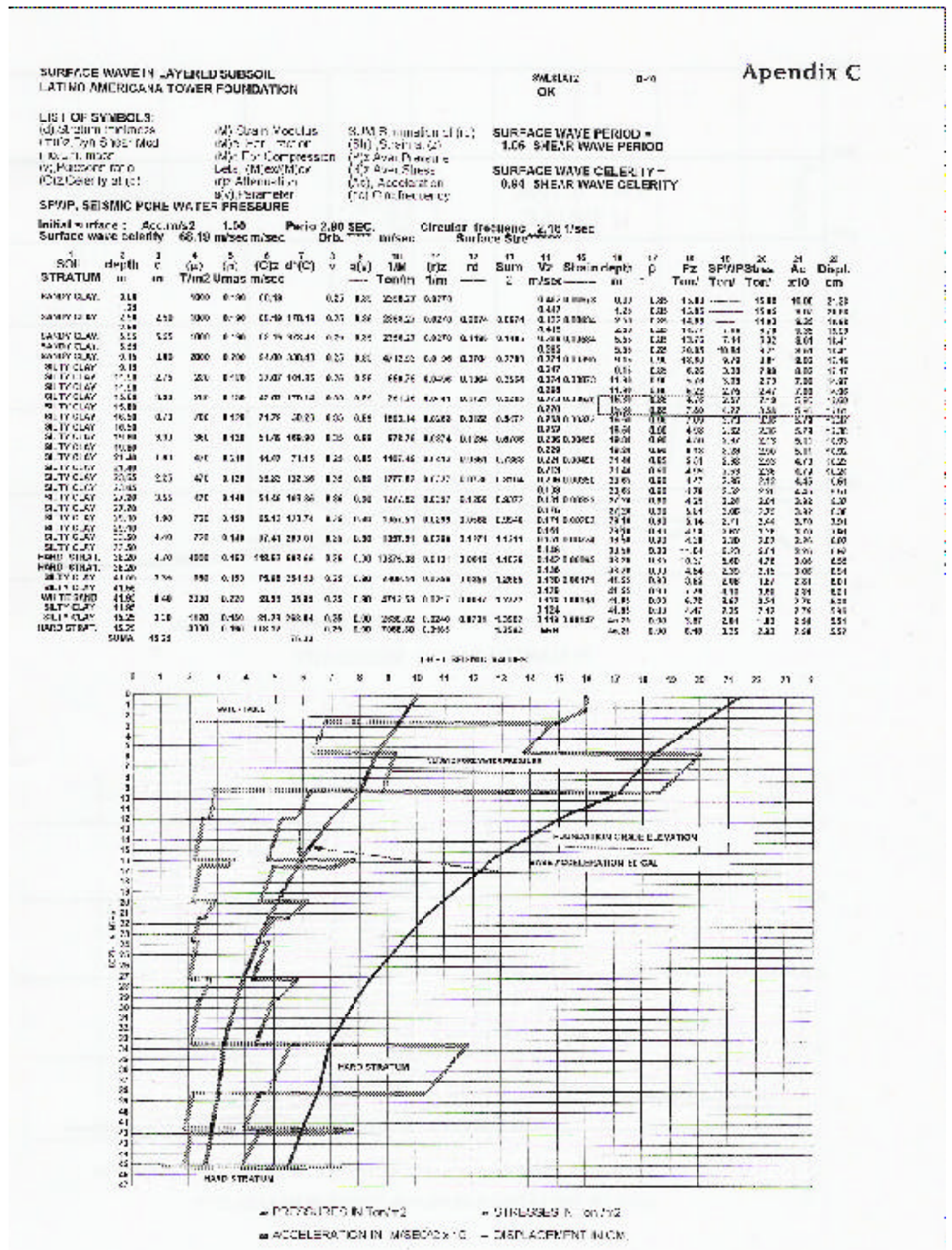

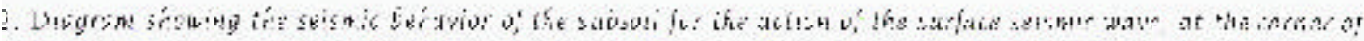

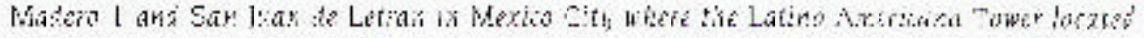

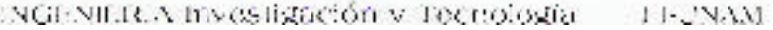

Figure 2. Diagram showing the seismic behavior of the subsoil for the action of the surface seismic wave, at the corner of Madero 1 and San Juan de Letran in M exico City where the Latino A mericana Tower located (continue...) 


\section{Information on the Problem}

An ilustrative analysis is pre sented a head, for a build ing acted by the horizon tal com po nent of the seis mic sur face wave, ap ply ing the con cepts in troduced here by the au thor.

The building is lo cated in the area of Mex ico City and will be analyzed by means of the seismogeodynamic the ory. The build ing has 6 floors in clud ing the roof level, and will be supported on a monolithic con crete box type "Lez" foun da tion at a depth of 6 meters con tain ing a base ment (11) (Zeevaert, 1998b).

The build ing foun da tion has a width of 12 me ters and a length of 24 meters. The structure will be formed of two rows of col umns in the longwise di rection and separated in the transversal direction 12.0 me ters, formimg struc tural bents every 4 me ters. The analysis of the factors pertaining the computation will be analized with a surface unit orbital ac cel era tion of $100 \mathrm{GAL}$, (1 meter/sec2), corresponding to the horizon tal com po nent of the sur face wave.

The ge om e try of the build ing, the weight on the floors and the foundation as well as the mass of the building and the floors elevation are given in calculation sheet number 1 .

The stra tig ra phy of the site is as fol lows

\begin{tabular}{|c|c|c|c|}
\hline Stratum & $(\mathbf{z})$ & (d) & Description \\
\hline & 0 & 0 & Ground Surface \\
\hline A1 & 1.0 & 2.0 & Silty-Clayey Sand \\
\hline S.W.T & 3.0 & & Surface Water Level \\
\hline A2 & 6.0 & 3.0 & Silty-Clay Sand \\
\hline B 1 & 8.50 & 2.5 & Soft Silty Clay \\
\hline B2 & 11.0 & 3.0 & Soft Silty Clay \\
\hline C & 15.0 & 3.0 & Soft Silty Clay \\
\hline D & 18.0 & 3.0 & Semi Rigid Silty Clay \\
\hline$E$ & 21.0 & 3.0 & Semi Rigid Silty Clay \\
\hline $\mathrm{F}$ & 24.0 & 3.0 & Rigid Silty Clay \\
\hline G & 26.0 & 2.0 & Rigid Silty-Clayey Sand \\
\hline $\mathrm{H}$ & 31.0 & 5.0 & Rigid Silty-Clayey Sand \\
\hline \multirow[t]{2}{*}{ I } & 35.0 & 4.0 & Rigid Silty-Clay \\
\hline & & & Rigid Stratum \\
\hline
\end{tabular}

(z) Depth of Strata, (d) Thickness of Strata in meters.

\section{Seismo-Geodynamic Computations}

Theo retically, the celerity of the surface wave is for clayey soils $94 \%$ from the celerity of the shear wave. The period takes the approximate value of $6.4 \%$ greater than the period of the shear wave (6) (Zeevaert, 1988c). There fore, the anal y sis of the shear wave will be made first, to obtain the period correspond ing to the sur face wave of 1.064 (Ts). The cal cu la tion is pre sented in cal cu la tion sheet num ber 2 .

Thephysicalcharacteristics of the soils, as well as the representative dynamic parameters are registed in calculation sheets 2 and 3 . They were care fully de ter mined in the lab o ra tory from spec imens of undisturbed soil samples. The dynamic soil rigidity $(\mu)$ was determined with "The Torsion free Vibration Pen du lum" (1)(Zeevaert).

The values of the dynamic strain moduli, Mez and $M C x$, were investigated with undisturbed soil samples in "The Hollandish Modified Chamber", designed by the author for this purpose.

The soil sam ple is con fined in the triaxial cham ber at a volu met ric stress rep resen ta tive of the oc tahedral field stress, there after a tor sional vi- bration is applied to the specimen and the vibration recorded. The above men tioned val ues corres- pond to the vertical expansion response (Mez), and $(M c x)$ for the di rect hor i zon tal com pres sion. From them the Re sponse Fac tor is de fined as fol lows

$$
\beta e x=M e x / M x z
$$

The value of the seismic soil rigidity $(\mu)$ and the response factor $\beta$ ex are found in cal cu la tion sheet 2 and 3 re spec tively (4)(Zeevaert, 1988). In cal cu la tion sheet number 2 , the maximum resonant pe riod of the ground is presented on the order of 1.850 sec onds corresponding to the fundamental period of the subsoil deposit and equivalent to that of the shear wave, hence the period for the 
horizontal surface wave is $1.064 \times 1.1 .850=1.968$ Seg. (5)(Zeevaert, 1996).

The com putation for the horizon tal com po nent of the sur face wave (6)(Zeevaert, 1988c) is given in sheet num ber 3 , from which the fol low ing in for mation was obtained with depth: the soil pressures, the seis mic pore water pres sure, (SPWP), the ef fective stresses, the hor izon tal soil dis place ments and ac celerations (7)(Zeevaert, 1998a).

The soil pore water pressure is of vital importance to analyze the soil shear stregth in stability problems of sandy soils, as the load capacity in foundations, slope stability, retention walls, seis mic sta bil ity of the ground sur face and other en gineering problems induced by destructive earthquakes $(4,7)(Z e e v a e r t, 1988$ b y 1998a) (Photo 1).

For the pres ent case it was found in calculation sheet num ber 3 , that the ac cel er a tion at the foun da tion grade el e va tion of the build ing at 6 meter depth, shows on the order of $77 \mathrm{Gal}(77 \mathrm{~cm} / \mathrm{sec} 2)$ with a displace ment of $7.54 \mathrm{~cm}$, cor re spond ing to a surface orbital acceleration of $100 \mathrm{Gal}$. See calculation sheet num ber 3, (9)(Zeevaert, 1973-1982, pp. 508).

With the data obtained in calculation sheet number 3 , the soil structureinteraction was performed for seis mic vertical ro tation of the building foundation structure (8)(Zeevaert, 1980), this in shown in cal cu la tion sheet num ber 4.

From the mentionedanalysis the follow in results are ob tained:

1. Acceleration at the center of mass of the building $1.694 \mathrm{~m} / \mathrm{seg}^{2}$, and the seismic surface wave period of $1.968 \mathrm{seg}$.

2. Overturning moment, the building consid ered rigid $258.48 \mathrm{Ton} \times \mathrm{m} / \mathrm{ml}$.

3. Coupled Foundation-Rigid structure period found of $1.059 \mathrm{seg}$.

4. Total shear at the foundation base $1.694 * 12.11=20.51 \mathrm{Ton} / \mathrm{ml}$.

5. Rigid vertical foundation rotation $(? \mathrm{v})=0.00382 \mathrm{Rad}$.
6. Soil-Foundation contact stresses because of the vertical rotation.

With the information obtained in calculation sheets $1,2,3$ and 4 , the anal y sis to find the seis mic acceleration in each floor of the building is achieved, as well as the shear forces act ing on the structure.

\section{Calculation Sheets 5a y 5b}

In calculation sheet $5 \mathrm{a}$, column 4 , the horizontal displacements have been computed bacause of the vertical ro tation $(\theta v)$ of the foun da tion and assum ing the build ing rigid. Hence ob tain ing a lin eal dis tri bu tion of the dis place ments in the floors with the height of the building. Furthermore, the dis placements because of the flexi bil ity of the floors acted by the shear forces. Have been added.

To ob tain the total dis place ments of the floors it is necessary to add those displacements be cause of the free pe riod of vi bra tion of the build ing and obtain finally the accelerations and shears in the floors of the building. See calculation sheet $7 \mathrm{~b}$.

Knowing the structure flexibility for each floor $(1 / k)$ per lineal meter the total displacements are calculated ( $\mathrm{S}$ ?). This calculation is found in computation sheets number 5a-b. To calculate the acceleration, the cou pled pe riod of vi bra tion was used, ob tained from the in di vid ual pe ri ods of the "Struc ture and fo un da tion rocking", respec tively.

The cal cu la tion is as fol lows

$$
\operatorname{To}^{\wedge} 2=T^{\wedge} 2+\operatorname{Ts}^{\wedge} 2
$$

Here

To Equivalent pe riod of the sys tem.

Ts Rocking period of the building, considered rigid.

Te Free pe riod of the build ing.

See com pu ta tion sheet num ber 4 . 


\section{Computation Sequence}

1. From the computation sheet number $5 a$, the displacements for each floor of the building, in duced by the vertical ro ta tion of the foundation are shown in col umn 4. To ob tain this action the foundation rotation is multiplied by the height of the floors, and the accelerationis obtained multi ply ingthe dis place ments bythesquare of the coupling circularfrecuency (Col umn 9).

\section{Couplingcircularfrequency $?=(2 \mathrm{p} / \mathrm{To})$}

2. In column 10 , the acceleration correction is performed with the help of (DAES) (9)(Zeevaert, 1973-1982) computation sheet number 4, to make it com pat ible with theam plification of the ac cel eration of $1.694 \mathrm{M} / \mathrm{s} 2$, ob tained at the cen ter of mass of the build ing be cause of the ver tical rotation of the foundation corresponding to "The design acceleration envelope spectrum", (Figure 3) (9)(Zeevaert, 1973-1982, pp. 510).

3. In computation sheet $5 \mathrm{a}$, column 11, the act ing shear forces are cal cu lated for the floors of the building. They are obtained multipling the mass by the acceleration corrected with "DAES" for all floors (Col umn 10). The grad ual sum gives the shear force along the height of the bulding. Col umns 12 and 14 in di cate the in cre ments of the seismic overturning moment and the sum the correspondingoverturning mo ment to which the dif fer ent floors of the struc ture are sub jected only because of the vertical rotation $(? \mathrm{v})$ of the foundation.

4. In computation sheet $5 b$ the accelerations of the floors may be high be cause the flex i bil ity of the struc ture. The ac cel era tions of the floors are ob tained multiplying the total displacements ( $\mathrm{S}$ ?) by the square of the circular frecuency $? \mathrm{o}^{2}=(6.2832 / \mathrm{To})^{2}$, column 10 and the ac cel er a tion is ad justed in pro portion to "DAES" as shown in col umn 11.

This value so ob tained is mul ti plied by the mass of the floors per lineal meter, to obtain the floor shear forces col umn 12, the sum of the floor shear forces per meter is found in col umn 13.

The final values for the floor shears and overturning moments correspond to the action of the surface wave, the values obtained are the following; for the base shear $20.64 \mathrm{Ton} / \mathrm{m}$ and for the adventurning moment $315.66 \mathrm{Ton} \times \mathrm{m} / \mathrm{ml}$. The soil foundation reaction stresses reported in calculation sheet 4 shall be inceased by a factor $315.7 / 258.48=1.22$.

5. In order to verify the total displacements ( $\mathrm{S}$ ?) and the correct final values for each floor, the cal cu la tion is respeated, thus ob tain ing the new floor shears column 12 , the sum of the shear floors is shown in col umn 13 , and the cal cu la tion fol lows in the next col umns.

\section{The Horizontal Rotation on the Floors}

Another important phenomenon is originated in the rigid structure of the foundation, because of the horizontal rotation (?h) induced by the equivolumetric shear wave. This action generates important torsion in the building floors, the phe nomenon is known as "Torsional Whipping Action", and is pres ent when the struc tural flexi bil ity is high mainly in the upper floors, as compared with the lower floors.

On account on the formerdis cus sion, the higher floorsaccelerate mo tivatingdamageto thestruc ture and col lapse in oc ca sions, caus ing dam age to ar chi tec tonic de tails in the build ing and the dis place ment of ob jects on the floors (Photo 2, 3 and 4).

This phenomenon has been obvious during earth quakes and has been fre quently ob served in the upper floors of the build ings, and fail ure of the building "Head Frames". The upper frames are usually designed with minor rigidity, hence with majorflexibility, as the interior and lower frames. The head frames are ex posed to a stron ger seis mic torsion. Such phenomenon has been very important in long build ings (Photos 5 and 6 ). 
The torsion is originated by the twist induced in the foundation at the supporting soil stratum by the shear wave (Appendix " $\mathrm{B}$ "). The increment in the acceleration in the structural head frames of the build ing is in creased to a value (a\%)n, with respect to the sym met rical con di tion, as an exam ple, this concept will be ap plied to the build ing here analize.

The seismic response of the elements is proportional to the ac cel er a tion, this is shown in com putationsheet $3 a$.

There fore, the in cre ment (a\%) of the ac tions in the floors can be cal cu lated to de ter mine the shear forces, the accelerationsand displacements along the length of the build ing, at the head-frames and in terme diate frames of the build ing.

With re spect to the val ues of the hor i zon tal rotation (?h) of the rigid building floors, a lineal dis tribution of the value (a\%) is obtained along the length of the build ing, permit ting the cal cu la tion of the build ing frames. The in cre ment in the dis placements, shear forces and tor sion mo ments from the symmetrical values are shown in computation sheet 6 .

The the o ret ical anal y sis to find in each case the order of magnitud of the value $(a \%)$, is obtained an a lyz ing the ro ta tion origi nated at the ground surface by the shear wave. The theoreticalanalysisis presented in appendix B, in wich the following is obtained

$$
\text { TANG a }=A z * T /(6.28 * C s)
$$

The in cre ment for the "Tor sional Whip ping Action" in shears, accelerations, and displacements in the building head-frames in the present problems is as fol lows:

(a) Ro ta tion of the rigid floor of the build ing.

Az Orbitalacceleration at the supporting stratum for the shear wave, cal cu la tion sheet 2 $0.99 \mathrm{~cm} / \mathrm{seg}^{\wedge} 2$.

Ts Pe riod of the shear wave $1.85 \mathrm{seg}$

CS Celerity of the supporting stratum $87 \mathrm{~cm} / \mathrm{seg}$ d Average displacement of foundation from the surface wave cal cula tion sheet 3 $8.93 \mathrm{~cm}$.

$\mathrm{L} / 2$ One half the length of the foundation $1200 \mathrm{~cm}$

\section{TANG $\mathrm{a}=\mathbf{0} \mathbf{0} 00338$}

Dis place ment for ro tation in head-frame $\mathrm{do}=4.06 \mathrm{~cm}$

Sym met ri cal dis place ment in the head-frame $\mathrm{d}=8.93 \mathrm{~cm}$

Total at the head-frame

Displacement ratio $(\mathrm{do}+\mathrm{d})=13.0 \mathrm{~cm}$

$\mathrm{R}=1.45$

Increment of ac tions at the head-frame

$$
(\mathrm{a} \%)=45 \%
$$

Call ? (Shear $n)=($ Shear $n) \times a \%$ the in cre ment of the sherar forces per lineal meter, based on the symmetrical case (Shear $n$ ), obtained for frames dis tant $(x)$ from the cen ter of ro ta tion of the floor. Hence, the fol low ing value for the shear along the build ing is

$$
(\text { Shear } n) x=(\text { Shear } n)\left(1+a^{*}(x) / L\right)
$$

The tor sion mo ment of each rigid floor in its plane is

$$
\mathrm{Tn}=2(\text { Shear } n) \times a L^{2} / 3
$$

Here $(L)$ is one half the length of the building. The result of the calculation of the "Torsional Whipping Action", is presented in computation sheetnumber 6 .

\section{Structural Period of Vibration of the Building Computation Sheets $7 a$ and $b$}

The free pe rio $d$ of vi bra tion of the build ing is cal cu lated with the well known method of "Holzer", used for the present problem in com pu ta tion sheet $7 \mathrm{~b}$ where the value is $T e=0.50 \mathrm{seg}$. 
Nev er the less, the au thor gives a method based on seismo-geodynamics, to find the period. This method is the same as the one applied to obtain the period of vibration of the soil mass. Here the Average Celerity of the shear wave is used, traveling across the build ingstruc ture.

In order to achieve the mentioned method it is necessary to stablish the correlation between the average of the dy namic rigidity shear modulus $(\mu)$ with the average rigidity $(K)$ of the building structure, also the correlation between the unit soil mass (?) with the unit mass corresponding to the floors weight of the build ing (Ap pen $\operatorname{dix} A$ ).

The fol low ing is ob tained per floor

For $(\mu)$, the structural equivalence is $(K) d / B$, Ton $/ \mathrm{m}^{2}$

For (?), the equiv a lence is M/Bd, Ton* $\underline{\mathrm{Seg}} 2 / \mathrm{m}^{4}$

The wave celerity of the building structureper floor is $\left(C_{z}\right)$, and the average celerity of the wave $\left(\mathrm{C}_{\mathrm{m}}\right)$,

$$
C_{2}^{\wedge} 2=(K) * d^{2} / m
$$

\section{Here}

(K) Structural rigidity per floor and per lineal meter, Ton/m.

M Mass per floor and per lineal meter, Ton* $\mathrm{Seg}^{2} / \mathrm{m} / \mathrm{ml}$.

B Width coresponding to the base of the building.

d Height be tween floors.

Knowing the averagece lerity $\mathrm{C}_{\mathrm{m}}$ and the height of the build ing $(\mathrm{H})$ from the sup port at the foun dation base, the pe riod cal cu lated

$$
\mathrm{Te}=4 *(\mathrm{H}) / \mathrm{C}_{\mathrm{m}^{\prime}} \text { Seg }
$$

The period of vibaration obtained with this method for the pro posed build ing is $\mathrm{Te}=0.498 \mathrm{seg}$, and used in com pu ta tion sheets $4,5 \mathrm{a}$ and $5 \mathrm{~b}$.

\section{Computation Sheet 8}

Shows a table to facilitatethe verification in the selection of column dimensions, to stablish the proper ri gid i ties to take the seis mic mo ments, axial and shear forces to which the building struc ture is subjected, taking in consideration the important "Torsional Whipping Action" in the structural frames of the build ing, (Cal cu la tion sheet 6 ).

\section{Conclusions}

Here is given a method of computation with the help of the "The Seismo-Geodynamic Theory" to an a lyze the ac cel era tions in the floors of build ings, and be able to forsee the forces act ing on all and each one of the floors, and cal cu late the nec es sary force to fix the ob jects to the floor, and an a lyze the build ing struc ture in order to with stand the seis mic forces for the as signed surface ac cel er a tion.

No tice, that the soil ac cel er a tion at the fo un dation grade el e va tion is on the order of $77 \mathrm{~cm} / \mathrm{seg}^{2}$ for $100 \mathrm{~cm} / \mathrm{seg}^{2}$ at the ground surface, and in the case of normal "Wipping Action" without torsion including the flexibility of the proposedbuilding struc ture. The ac cel era tion at the fo un da tion grade elevation is $169.4 \mathrm{~cm} / \mathrm{seg}^{2}$, and at the roof floor of the build ing is on the order of $251.5 \mathrm{~cm} / \mathrm{seg}^{2}$ (Computation sheet $5 b$ ).

When the to r sional whip ping is con sid ered then this value in creases to $1.45 * 251.5=364.66 \mathrm{~m} / \mathrm{seg}^{2}$ at the Head-Frame the above phenomenon in dicates the im por tance to learn on the seis mic sta bil ity of the build ing.

Therefore, when the phenomenon here in de scribed is not prop erly con sid ered in de sign, to re sist adequately the destructive seismic forces, and be cause of exces sive struc tural flexi bil ity $(1 / K)$, and the displacements in the floors are not restricted, then damage may be expected and even structural collapse. During destructive earthquakes (9)(Zeevaert, 1973-1982) these actions have been frequently ob served in Mexico City and other cit ies (Photos 1-6).

"The Tor sional Whip ping Ac tion" takes place in all the floor levels of the build ing in duced by the 
combined vertical (?v) and horizontal (?h) rotations on the foundation. Hence, when the structure shows very flex i ble it is nec es sary to re duce its flexibility.

"Torsional Whipping Ac tion" is frequently present in buildings durung destructiveearthquakes, the head-frames take the worst of the tor sional rota tion of the build ing with larger forces in all in termediate frames, than for the symmetrical case. Hence, it is necessary to re in force them, accordingly with the results of the calculation as here described.

Computation sheet 8 gives a pro ce dure to facilitate the elec tion of the size of col umns and the rigid ity of the frames for the build ing struc ture.

The au thor calls to the im por tance on the study and knowl edge of the seis mic phys i cal con di tions of the sub soil at the site, as the stratigraphy and the quan ti ta tive dy nam i cal soil prop er ties in all the strata fo rm ing the sub soil de posit for the requiered depth. The seismo-geodynamic behavior of the sub soil has an im portant and basic bear ing in the calculation results on the seis mic forces act ing in the struc ture of the build ing and its foun da tion, as well as in any other seis mic prob lem per tain ing the soil de posit.

\section{Gratitude}

Finally, the au thor whiches to ac knowl edge the assistance of his sec re tary Zita del Carmen Vázquez for her interest in helping to obtain a better and cleaner edi tion of the sub ject, and not less, to her for mer sec re tary and now teacher Diana Alpizar de Balseca for the orthographycal manuscript revision.

Un der stand ing na ture' s phenom ena is a timedifficult task, for thesci en tist en gi neer, to dis cover with out dispair"

Leo nardo Zeevaert W. (1984).

\section{Appendix A}

Analysis to find the Structural Celerity of the Buildings, Related to the Soil Celerity in Seismo- Geodynamics, the soil celerity in Seismo-Geodynamics is given as fol lows:

$$
\mathrm{C}^{2} \mathrm{~s}=\mu / ?,(\mathrm{~m} / \mathrm{s})^{2}
$$

The dynamic soil rigidity for the shear stress distortion is

$\mu=$ ? $\mathrm{t} /$ ?? Ton $/ \mathrm{m}^{2}$, and the unit mass $?=\mathrm{W} / \mathrm{g}$, Ton*Seg${ }^{2} / \mathrm{m}^{4}$, and $W$ is the unit weight Ton $/ \mathrm{m}^{3}$.

The distortion in a vertical selection " $d$ " is $? ?=? \mathrm{~d} / \mathrm{d}$, here $? \mathrm{~d}$ is the relative horizontaldisplace ment of the ver tical sec tion " $d$ " hence

$$
\mu=? \mathrm{t}^{*} \mathrm{~d} / ? \mathrm{~d}
$$

For the struc ture the ri gid ity per floor and lin eal meters is $\mathrm{K}=$ ? $\mathrm{F} /$ ? $\mathrm{d}$ or $\mathrm{K}=$ ? $\mathrm{t}^{*} \mathrm{~B} / \mathrm{d}$ in $\mathrm{Ton} / \mathrm{m}^{2}$, from which ac cord ing to (2)(Zeevaert) the fol low ing is obtained

$$
\mu=\underline{\mathrm{K}^{*} \mathrm{~d} / \mathrm{B}}, \operatorname{Ton} / \mathrm{m} 2
$$

In the structure the mass per floor and lineal meter $M=w^{*} d * B / g$, in Ton*Seg $2 / m^{2}$, and the equivalent unit mass is

$$
?=\mathrm{M} / \mathrm{B}^{*} \mathrm{~d}, \mathrm{Ton} * \mathrm{Seg}^{2} / \mathrm{m}^{4}
$$

From the for mer anal y sis, the struc tural ce ler ity for the struc ture is govern by the fol lowing formula

$$
\mathrm{C}^{2} \mathrm{~s}=\underline{\mathrm{K}^{*}} \underline{\underline{\mathrm{d}^{2}}} \underline{\underline{M}},(\mathrm{~m} / \mathrm{s})^{2}
$$

\section{$X$. Appendix B}




\section{Foundation Maximum Angle of Torsion because of the Seismic Equivolumetric or Shear Wave. Horizontal Ro ta tion of the BoxType Foun da tion}

The equa tion gov ern ing the shear wave, for $z=0$

$$
Y_{x y}=Y_{0} \operatorname{COS}(2 \pi z / H) \operatorname{SIN}(2 \times 3.14 / T(t-x / C s)
$$

Here for $z=0$

$Y_{x y}$ Horizontalsheardisplacement

$Y_{0}$ Maximum horizontal surface shear displacement

$T \quad$ Wave pe riod and length $L=T x C s$

$t$ Any time

$X$ Positioncoordinate

CS Wavecelerity

The derivative of the equa tion ( 1 ) for $z=0$, repres ents the sur face ro ta tion of the shear wave, is maximum when $\mathrm{t}=\mathrm{T} / 2$ y $\mathrm{x}=\mathrm{L} / 2$, therefore:

$$
d Y_{x y} / d x=Y_{0}((2 \times 3.14 / T) / C s) \cos p(t-x / C s
$$

sub sti tut ing val ues to ob tain the maxi mum for $z=0$

$$
d Y_{x y} / d x=T A G . \alpha=Y_{0}(2 \times 3.14 / T) / C s
$$

Here $Y_{0}=A z / p^{\wedge} 2$, for $x=L / 2, Y_{0}=A z /(2 \times 3.14 / T)^{\wedge} 2$, sub sti tut ing $\mathrm{t}=\mathrm{T} / 2$ the max i mum $\mathrm{ro}$ ta tion value is

$$
?_{x y}=A z * T / 6.28 \mathrm{Cs}
$$

Here $A z$ is the ac cel er a tion of the stra tum holding the foundation structure, which rotates an angle ?

$$
\text { TANG } ?_{x y}=A z * T / 6.28 * C s, \text { TAG } ?_{x y}=a
$$

Computation sheet 10. 


\section{Apendix C}

\section{Definitions of the subsoil physical formulas for the analysis for the seismo-geodynamic theory used in calculation in figure 2}

\section{Column}

1. Soil stra tum clasification

2. Depth

3. Thick ness of each stratum

4. Effective stress, (weight of soil $\gamma_{2}$ )

5. Water con tent $\omega$, soil degree of sat u ration

$\begin{array}{ll}\mathbf{z} & \mathbf{m} \\ \mathbf{d} & \mathbf{m} \\ \sigma \varepsilon \mathbf{0} & \text { Ton } / \mathbf{m}^{2} \\ \mathbf{s} \% & \\ \mu_{z} & \text { Ton } / \mathbf{m}^{2} \\ \rho_{z} & \text { Ton*sec } 2 / \mathbf{m}^{4} \\ v & \\ \mathbf{C}_{z} & \mathbf{m} / \mathbf{s e c}=\sqrt{(\mu / \rho)_{z}}\end{array}$

6. Soil dynamic ri gid ity ref. 6 chap ter $\mathbf{V}$

7. Unit mass

8. Poisson's ratio

9. Shear wave ce ler ity in each stra tum

10. Depth exponentfactor $a(v)=\sqrt{1-\alpha^{2}(1-2 v) / 2(1-v)}$ ref. 6 page 48

11. Re sponse fac tor ref. 6 page 98-100

$\beta_{c x}=$ Mez/Mcx

12. Seis mic com pres sion modu lus ref. $\mathbf{6}$ page $\mathbf{4 8}$

13. Circularfrequency $1 / M d=2 \rho * C_{z}^{\wedge} 2 /(1-v)$

14. Attenuation, depthfactor

15. Depht fac tor for each stra tum

fc

16. Sum of fac tors with depth

$a(v)$

17. Surface unit strain

18. Or bital ve loc ity, $\mathrm{fc}=$ cir cu lar fre quency

19. Unit strain with depth

20. Sourface wave soil pres sure

21. Seis mic pore water pres sure in the soil

22. Seis mic wave ef fec tive stress

23. Acceleration with depth

24. Surfaceacceleration

25. Horizon tal dis placement with depth

$(\mathbf{r})_{z}=\left(\mathbf{p}_{z} \mathbf{c z}\right) * a(v)$

$(r)^{d}$

$\sum(\mathbf{r})^{\mathrm{d}}$

$\varepsilon_{0}=\mathrm{Vo}_{\mathrm{o}} \mathrm{Co}_{\mathrm{o}}$

$\mathrm{Vz}=\mathrm{Az} / \mathrm{fc}$

$\varepsilon_{\mathrm{z}}=\mathrm{Vo}_{0} * \mathrm{e}^{-\mathrm{rz}} / \mathrm{Cz}$

$\mathrm{Pz}=(2 \rho /(1-v)) * \mathrm{Cz}^{*}\left(\mathrm{Vo}^{*} \mathrm{e}^{-r}\right)$

(SPWP) ref. 6 chap ter 5

$\sigma z=P z-(S P W P) T o n / m^{2}$

Az $\mathrm{m} / \mathrm{sec}^{2}=$ As* $^{*} \varepsilon z / \mathrm{eo}^{2}$

Ao $\mathrm{m} / \mathrm{sec}^{2}$

$\delta z \mathrm{~m}=\mathrm{Az} / \mathrm{fc}^{\wedge} \mathbf{2}$ 


\section{References}

1. Zeevaert-Wiechers L. Teoría y práctica del péndulo de torsión. División de Estudios de Posgrado de la Facultad de Ingeniería, UNAM. D-49.

2. Zeevaert-Wiechers L. El uso de la cámara holandesa modificada para la investigación de los parámetros dinámicos del suelo. División de Estudios de Posgrado de la Facultad de Ingeniería, UNAM.

3. Zeevaert-Wiechers L. (1988a). Equipos para la investigación de los parámetros dinámicos del suelo. Boletín de Vías, No.90, Sede Manizales, Universidad EAFIT, Medellín, Colombia y SMMS, DEPFI, UNAM.

4. Zeevaert-Wiechers L. (1988b). Seismic$G$ eodynamics of the $G$ round $S$ urface and Building Foundations. SMMS e impresora internacional, Cap.V, VI, pp.60, Apéndice II.

5. Zeevaert-Wiechers L. (1996). The Seismic-Geodynamics in the design of foundations in difficult subsoil conditions. Guest lecture $3^{\text {rd }}$. International Symposium on Environmental Geotechnology, Vol. 1, pp.
19-69, San Diego, California. Junio 10-12, Sponsored by Lehigh and Massachusetts-Lowel Univer sities.

6. Zeevaert-Wiechers L. (1988c). Seismic-Geodynamics of the Ground Surface and Building Foundations. SMMS e Impresora Internacional, Apéndice 1.

7. Zeevaert-Wiechers L. (1998a). Análisis físico sobre licuación en mecánica y dinámica de suelos. SMMS, México.

8. Zeevaert-Wiechers L. (1980). Interacción suelo-estructura de cimentaciones superficiales y profundas sujetas a cargas estáticas y sísmicas. Edito rial Limusa, México.

9. Zeevaert-Wiechers L. (1972-1982). Foun dation Engi neering for D iffi cult Subsoil C ondi tions. Van Nostrand-Reinhold, Chap. XII, pp. 508, New York, USA.

10. Zeevaert-Wiechers L. (1964). Structural Steell Building Frames in Earth quake Engineering. Proceedings Steel Utilization Congress, Luxemburgo, octubre.

11. Zeevaert-Wiechers L. (1998b). A nálisis de la cimentación Tipo "Lez". Universidad Nacional Autónoma de México, México. 


\section{Ilustrative Seismic Analysis of Foudantion and Building Behavior using "The Seismo-Dynamic Theory"}

PROBLEM

BUILDING FOUNDATION

BUILDING FOUNDATION

COMPENSATED FOUNDATION

TOTAL COMPENSATION AT 6.0 m MTRS. DEPTH

Weight of foundation and walls

Weight of ground floor

FLOOR LEVELS

Height between floors

Ground floor

Basement and foundation

Height of building from foundation grade elev. total

\section{CENTER OF MASS}

Foundation structure

Basement floor

Floor levels

$\begin{array}{ll} & 1^{\circ} \\ & 2^{\circ} \\ & 3^{\circ} \\ & 4^{\circ} \\ & 5^{\circ} \\ \text { ROOF } & 6^{\circ} \\ & \\ \text { HEIGHT OF MASS CENTER } \\ \text { MASS PER LINEAL METER 9.90 } \times 12 / 9.81 \\ \text { FREE HEIGHT FOR WIND ACTION }\end{array}$

D-19

\author{
WIDTH $\quad 12.00$ Mtrs. \\ LENGHT $\quad 24.00$ Mtrs.
}

\begin{tabular}{|c|c|c|c|}
\hline & & & $\begin{array}{c}\text { Ton } / \mathrm{m}^{2} \\
10.00\end{array}$ \\
\hline & & & -2.00 \\
\hline & & & -1.30 \\
\hline & & SUM & 6.70 \\
\hline 6 & 1.10 & Ton/m² & 6.60 \\
\hline 3.2 MTRS. & & 5 & 16.00 \\
\hline & & & 3.50 \\
\hline & & & 6.00 \\
\hline & & & 25.50 \\
\hline
\end{tabular}

$\mathbf{T} / \mathbf{m}^{2}$

Mtrs

Ton $\times \mathbf{m}$

WEIGHT

HIGHT

MOMENT

2.0

1.00

2

1.30

6.00

7.8

1.10

9.50

10.45

1.10

12.70

13.97

1.10

15.90

17.49

1.10

19.10

21.01

1.10

22.30

24.53

1.10

25.50

28.05

9.90

125.3

\begin{tabular}{|l|l}
\hline 12.66 & Mtrs. \\
\cline { 1 - 1 } 12.11 & Ton*seg^ 2/m \\
\cline { 1 - 1 } 19.50 & Mtrs. \\
\hline
\end{tabular}

\section{CALCULATION SHEET 1}


SHEAR WAVE IN LAYERED SUBSOIL

List of symbols:
SHWLS298 D-20 d Stratum thickness

$\mu \quad$ Dynamic soil modulus

$\rho$ Soil unit density

$\delta \quad$ Displacement in $\mathrm{YZ}$

12.00 Mtrs. Semi-Largo Cimentation
$\mathbf{A z}=\quad$ Orbital acceleration
$\gamma$
Distortion
Vz Orbital velocity
foundation rotation
(tau)yz Shear Sress yz
(tau)yx Shear Sress yx
z Depth of Stratum

\begin{tabular}{|c|c|c|c|c|c|c|c|c|c|c|c|c|c|c|c|}
\hline \multirow{2}{*}{\multicolumn{4}{|c|}{$\begin{array}{ccc}1 & 2 & 3 \\
\text { SURFACE } & \text { ORBITAL VALUES }\end{array}$}} & \multirow{3}{*}{$\begin{array}{c}5 \\
\mathrm{Ao}= \\
\mathrm{m} / \mathrm{sec}\end{array}$} & \multirow{2}{*}{$\begin{array}{c}6 \\
1.00\end{array}$} & \multirow{2}{*}{$\begin{array}{c}7 \\
\mathrm{~m} / \mathrm{s}^{2}\end{array}$} & \multirow{2}{*}{$\begin{array}{c}8 \\
\text { Vo }\end{array}$} & \multirow{3}{*}{$\begin{array}{c}9 \\
0.294 \\
0.0867\end{array}$} & \multirow{3}{*}{$\begin{array}{c}10 \\
\text { M/sec } \\
m\end{array}$} & \multirow{3}{*}{$\begin{array}{l}11 \\
T= \\
\text { Fs }\end{array}$} & \multirow{3}{*}{$\begin{array}{c}12 \\
1.850 \\
3.397\end{array}$} & \multirow{3}{*}{$\begin{array}{c}13 \\
\text { seg } \\
\text { Rad }\end{array}$} & \multirow{3}{*}{14} & \multirow[t]{3}{*}{15} & \multirow{3}{*}{16} \\
\hline & & & & & & & & & & & & & & & \\
\hline AVE. CE & ERITY & $\mathrm{Cz}$ & 75.69 & & \multicolumn{3}{|c|}{ SURF. DISPLACEMENT } & & & & & & & & \\
\hline \multirow[t]{3}{*}{ SOIL } & $z$ & d & $\mu$ & $\rho$ & $\mathrm{Cz}$ & Czxd & $\mathrm{Ni}$ & $\mathbf{A i}$ & $\mathbf{B i}$ & $\delta$ & (tau)yz & $A z$ & (tau)yx & $\delta$ & $\gamma$ \\
\hline & & m & Ton/m ${ }^{2}$ & mass & $\mathrm{m} / \mathrm{sec}$ & & & & & $\mathbf{M}$ & $\mathrm{T} / \mathrm{m}^{2}$ & $\mathrm{~m} / \mathrm{sec}^{2}$ & $\mathrm{~T} / \mathrm{m}^{2}$ & $\mathrm{Cm}$ & Rad. \\
\hline & 0.00 & 0.00 & 1030 & 0.136 & 87.0 & 87.03 & 0.00 & 1.000 & 0.000 & 0.0867 & 0.00 & 1.000 & 3.48 & 8.667 & 0.0034 \\
\hline $\mathrm{A} 1$ & 1.00 & 1.00 & 1030 & 0.136 & 87.0 & 87.03 & 0.000 & 0.999 & 0.001 & 0.0867 & 0.00 & 1.000 & 3.48 & 8.667 & 0.0034 \\
\hline SWT & 3.00 & 2.00 & 1030 & 0.136 & 87.0 & 174.05 & 0.002 & 0.997 & 0.002 & 0.0866 & 0.14 & 0.999 & 3.48 & 8.660 & 0.0034 \\
\hline $\mathrm{A} 2$ & 6.00 & 3.00 & 380 & 0.136 & 52.9 & 158.58 & 0.009 & 0.982 & 0.008 & 0.0861 & 0.41 & 0.993 & 2.10 & 8.608 & 0.0055 \\
\hline $\mathrm{B} 1$ & 8.50 & 2.50 & 230 & 0.144 & 40.0 & 99.91 & 0.011 & 0.978 & 0.011 & 0.0813 & 0.80 & 0.938 & 1.59 & 8.131 & 0.0072 \\
\hline B2 & 11.50 & 3.00 & 230 & 0.141 & 40.4 & 121.16 & 0.016 & 0.969 & 0.013 & 0.0709 & 1.12 & 0.818 & 1.37 & 7.089 & 0.0071 \\
\hline C & 15.00 & 3.50 & 397 & 0.131 & 55.1 & 192.68 & 0.012 & 0.977 & 0.009 & 0.0543 & 1.42 & 0.627 & 1.33 & 5.432 & 0.0052 \\
\hline$D$ & 18.00 & 3.00 & 600 & 0.116 & 71.9 & 215.76 & 0.005 & 0.990 & 0.005 & 0.0407 & 1.67 & 0.469 & 1.15 & 4.068 & 0.0041 \\
\hline$E$ & 21.00 & 3.00 & 850 & 0.114 & 86.3 & 259.05 & 0.003 & 0.993 & 0.004 & 0.0319 & 1.82 & 0.369 & 1.07 & 3.194 & 0.0034 \\
\hline $\mathrm{F}$ & 24.00 & 3.00 & 1500 & 0.180 & 91.3 & 273.86 & 0.003 & 0.994 & 0.002 & 0.0253 & 1.93 & 0.292 & 1.41 & 2.532 & 0.0032 \\
\hline G & 26.00 & 2.00 & 1047 & 0.110 & 97.6 & 195.12 & 0.001 & 0.998 & 0.002 & 0.0213 & 2.08 & 0.246 & 0.78 & 2.131 & 0.0030 \\
\hline $\mathrm{H}$ & 31.00 & 5.00 & 1740 & 0.200 & 93.3 & 466.37 & 0.008 & 0.984 & 0.003 & 0.0173 & 2.13 & 0.200 & 1.10 & 1.729 & 0.0031 \\
\hline \multirow[t]{2}{*}{ I } & 35.00 & 4.00 & 1130 & 0.110 & 101.4 & 405.42 & 0.004 & 0.991 & 0.004 & 0.0109 & 2.29 & 0.126 & 0.41 & 1.095 & 0.0029 \\
\hline & & 35.00 & & AVE. A & CELERITY & 75.69 & & & & 0.0028 & 2.32 & 0.032 & 0.00 & & \\
\hline
\end{tabular}

SEISMIC VALUES IN SUBSOIL PROFILE

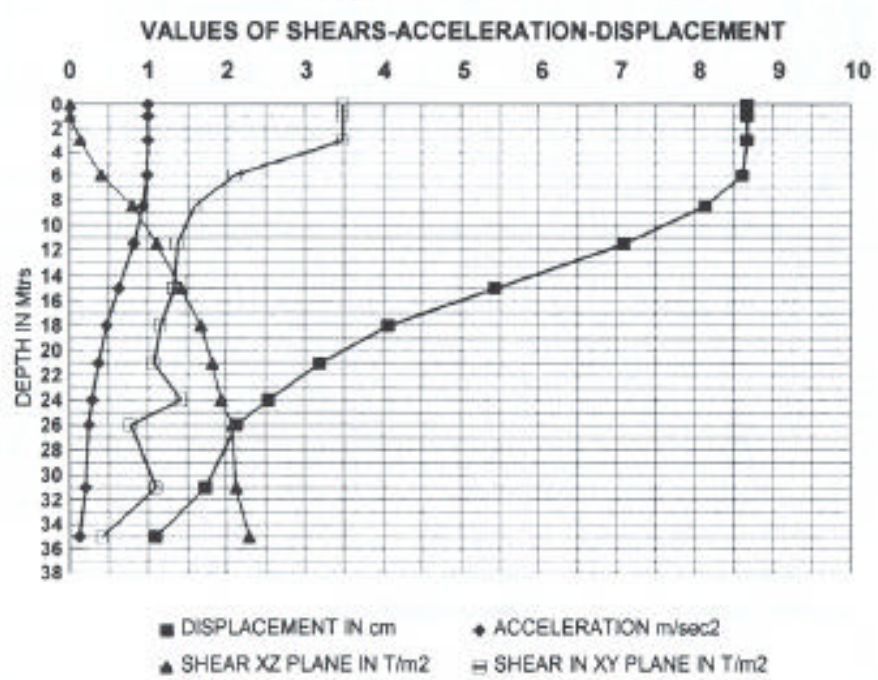

\section{CALCULATION SHEET 2}


DOI:http://dx.doi.org/10.22201/fi.25940732e.2005.06n1.005

Acceleration in the Building Floors Using the Seismo-Geodynamic Theory

SURFACE WAVE IN LAYERED SUBSOIL

List of symbols:

$\begin{array}{ll}\text { (d) } & \text { Stratum thickness } \\ \text { (mu) } & \text { Dynamic shear modulus } \\ \text { rho } & \text { Unit mass } \\ \text { (v) } & \text { Poisson ratio } \\ \text { (C)z } & \text { Celerity at centre stratum } \\ \text { a(v) } & \text { Paremeter } \\ \text { T } & \text { Period }=\quad \text { Ts/0.94 }\end{array}$

$\begin{array}{ll}\text { I/(M) } & \text { Stress modulus } \\ \text { (M) } & \text { Starin modulus } \\ \text { (M)e } & \text { Traction modulus } \\ \text { (M)C } & \text { Compression } \\ (r) z & \text { Atenuation } \\ \text { SUM } & \text { Summation of }(r d) \\ \text { (z) } & \text { Depht }\end{array}$

2 (rho)*Cz^ 2/(1-v)

\begin{tabular}{|c|c|c|c|c|}
\hline & Strain at depth Z & Sand & $\alpha$ & 0.92 \\
\hline & Aver. Pressure & SILTY & & \\
\hline
\end{tabular}

(S)z $\quad$ Aver. Stress

(Az) Orbital Acceleration $\mathrm{Az}=\mathrm{Ao}(\varepsilon \zeta / \varepsilon 0)$

(pc) Circular frequency

(Vz) Orbital velocity

sPwP SEISMIC PORE WATER PRESSURE

$\begin{array}{lll}\text { SURFACE ORBITAL LACL } & A 0= & 1.00 \mathrm{M} / \mathrm{s}^{2}\end{array}$

SURFACE CELERITY

(C) $0=$

$81.80 \mathrm{M} / \mathrm{s}$
$T=1.968 \mathrm{sec} \quad \mathrm{FC}=3.192 \mathrm{rad} \quad(\mathrm{Vo})=0.313 \mathrm{M} / \mathrm{sec}$

(ع) $\quad 0.00383$ ORBITAL STRAIN

\begin{tabular}{|c|c|c|c|c|c|c|c|c|c|c|c|c|c|c|c|c|c|c|c|c|}
\hline \multirow{3}{*}{ SOIL } & \multirow{3}{*}{$z$} & \multirow{3}{*}{$\begin{array}{l}\text { d } \\
\text { m }\end{array}$} & \multirow{3}{*}{$\begin{array}{c}\sigma \varepsilon 0 \\
T / m^{2}\end{array}$} & \multirow{3}{*}{$\begin{array}{l}\omega \\
\%\end{array}$} & \multirow{3}{*}{$\begin{array}{c}\mu \\
T / m^{2}\end{array}$} & \multirow{3}{*}{$\begin{array}{c}\rho \\
\text { mass }\end{array}$} & \multirow{3}{*}{$\begin{array}{l}v \\
\text { nu }\end{array}$} & \multirow{3}{*}{$\begin{array}{c}\mathrm{c} \\
\mathrm{m} / \mathrm{sec}\end{array}$} & \multirow{3}{*}{$\begin{array}{c}a(v) \\
-\end{array}$} & \multirow{3}{*}{$\begin{array}{c}\mathrm{BCx} \\
-\end{array}$} & \multirow{3}{*}{$\begin{array}{c}1 / \mathrm{M} \\
\text { Ton } / \mathrm{m}^{2}\end{array}$} & \multirow{3}{*}{$\begin{array}{c}r \\
1 / m\end{array}$} & \multirow{3}{*}{$\begin{array}{l}\text { id } \\
-\end{array}$} & \multirow{3}{*}{$\begin{array}{c}\text { sum } \\
-\end{array}$} & \multirow{3}{*}{$\begin{array}{c}\text { STRAIN } \\
-\end{array}$} & \multirow{3}{*}{$\begin{array}{c}\mathrm{Pz} \\
\mathrm{T} / \mathrm{m}^{2}\end{array}$} & \multirow{3}{*}{$\begin{array}{l}\text { spwp } \\
T / m^{2}\end{array}$} & \multicolumn{3}{|c|}{$\times 10$} \\
\hline & & & & & & & & & & & & & & & & & & $(\mathbf{S}) \mathrm{z}$ & Acc & DEPL. \\
\hline & & & & & & & & & & & & & & & & & & $\mathrm{T} / \mathrm{m}^{2}$ & $\mathrm{~m} / \mathrm{s}^{2}$ & $\mathrm{~cm}$ \\
\hline & 0.00 & 0.00 & 0.00 & 0.00 & 1030.00 & 0.136 & 0.25 & 81.80 & 0.85 & 0.80 & 2426.95 & 0.0332 & 0.0000 & 0.0000 & 0.003829 & 9.294 & & 9.294 & 10.00 & 9.81 \\
\hline A1 & 1.00 & 1.00 & 1.80 & 50.00 & 1030.00 & 0.136 & 0.25 & 81.80 & 0.85 & 0.80 & 2426.95 & 0.0332 & 0.0332 & 0.0332 & 0.003705 & 8.991 & & 8.991 & 9.67 & 9.49 \\
\hline SWT & 3.00 & 2.00 & 5.40 & 50.00 & 1030.00 & 0.136 & 0.25 & 81.80 & 0.85 & 0.80 & 2426.95 & 0.0332 & 0.0663 & 0.0995 & 0.003467 & 8.414 & & 8.414 & 9.05 & 8.88 \\
\hline$A 2$ & 6.00 & 3.00 & 6.00 & 125.00 & 380.00 & 0.136 & 0.25 & 49.69 & 0.85 & 0.80 & 895.38 & 0.0546 & 0.1638 & 0.2634 & 0.002943 & 2.635 & 1.464 & 1.171 & 7.68 & 7.54 \\
\hline B1 & 8.50 & 2.50 & 7.50 & 300.00 & 230.00 & 0.144 & 0.35 & 37.57 & 0.90 & 0.90 & 625.32 & 0.0765 & 0.1912 & 0.4545 & 0.002431 & 1.520 & 0.800 & 0.720 & 6.35 & 6.23 \\
\hline B2 & 11.50 & 3.00 & 9.00 & 300.00 & 230.00 & 0.141 & 0.35 & 37.96 & 0.90 & 0.90 & 625.32 & 0.0757 & 0.2270 & 0.6815 & 0.001937 & 1.211 & 0.638 & 0.574 & 5.06 & 4.95 \\
\hline c & 15.00 & 3.50 & 13.70 & 225.00 & 397.00 & 0.131 & 0.35 & 51.75 & 0.90 & 0.90 & 1079.35 & 0.0555 & 0.1943 & 0.8759 & 0.001595 & 1.722 & 0.906 & 0.816 & 4.17 & 4.09 \\
\hline D & 18.00 & 3.00 & 18.00 & 100.00 & 600.00 & 0.116 & 0.35 & 67.60 & 0.90 & 0.90 & 1631.26 & 0.0425 & 0.1275 & 1.0033 & 0.001404 & 2.291 & 1.206 & 1.085 & 3.67 & 3.60 \\
\hline $\mathrm{E}$ & 21.00 & 3.00 & 21.50 & 225.00 & 850.00 & 0.114 & 0.35 & 81.17 & 0.90 & 0.90 & 2310.95 & 0.0354 & 0.1062 & 1.1095 & 0.001263 & 2.918 & 1.536 & 1.382 & 3.30 & 3.24 \\
\hline $\mathrm{F}$ & 24.00 & 3.00 & 25.00 & 50.00 & 1500.00 & 0.180 & 0.25 & 85.81 & 0.85 & 0.80 & 3534.40 & 0.0316 & 0.0949 & 1.2044 & 0.001148 & 4.059 & 2.255 & 1.804 & 3.00 & 2.94 \\
\hline G & 26.00 & 2.00 & 27.75 & 250.00 & 1047.00 & 0.110 & 0.35 & 91.71 & 0.90 & 0.90 & 2846.55 & 0.0313 & 0.0627 & 1.2670 & 0.001079 & 3.071 & 1.616 & 1.454 & 2.82 & 2.76 \\
\hline H & 31.00 & 5.00 & 29.00 & 45.00 & 1740.00 & 0.200 & 0.25 & 87.68 & 0.85 & 0.80 & 4099.90 & 0.0309 & 0.1547 & 1.4218 & 0.000924 & 3.789 & 2.105 & 1.684 & 2.41 & 2.37 \\
\hline \multirow[t]{2}{*}{1} & 35.00 & 4.00 & 31.00 & 120.00 & 1130.00 & 0.110 & 0.35 & 95.27 & 0.90 & 0.90 & 3072.21 & 0.0302 & 0.1206 & 1.5424 & 0.000819 & 2.516 & 1.324 & 1.192 & 2.14 & 2.10 \\
\hline & & 35.00 & & & & & & & & & & & & & & & & & & \\
\hline
\end{tabular}

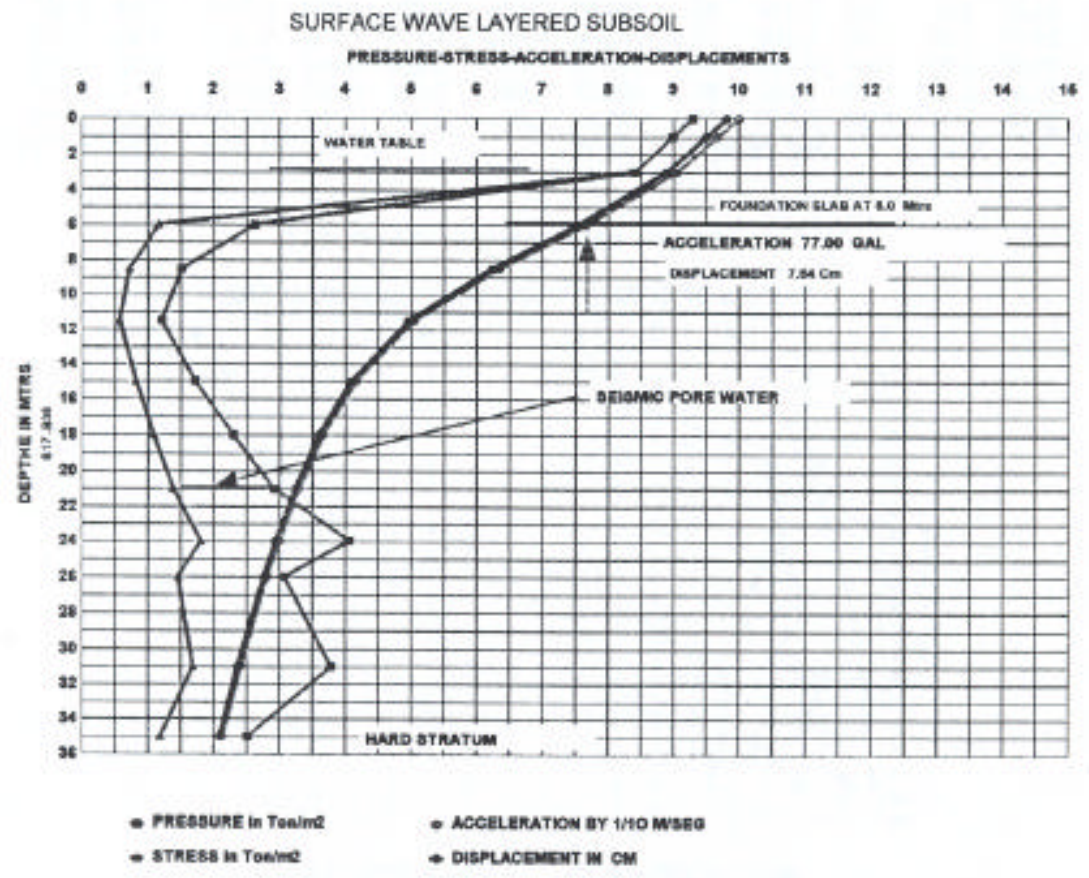

\section{CALCULATION SHEET 3}


DOI:http://dx.doi.org/10.22201/fi.25940732e.2005.06n1.005

L. Zeevaert-Wiechers

SURFACE WAVE IN LAYERED SUBSOIL

List of symbols:

$\begin{array}{ll}\text { (d) } & \text { Stratum thickness } \\ \text { (mu) } & \text { Dynamic shear modulus } \\ \text { rho } & \text { Unit mass } \\ \text { (v) } & \text { Poisson ratio } \\ \text { (C)z } & \text { Celerity at centre stratum } \\ \text { a(v) } & \text { Paremeter } \\ \text { T } & \text { Period }=\quad \mathrm{Ts} / 0.94\end{array}$

SWLS198 D-20

$\begin{array}{ll}\text { I/(M) } & \text { Stress modulus } \\ \text { (M) } & \text { Strain modulus } \\ \text { (M)e } & \text { Traction modulus } \\ (M) C & \text { Compression } \\ (r) z & \text { Atenuation } \\ \text { SUM } & \text { Summation of }(r d) \\ \text { (z) } & \text { Depht }\end{array}$

2 (rho)*Cz^ 2/(1-v)

\begin{tabular}{|c|c|c|c|c|}
\hline ( $\varepsilon$ & Strain at depth Z & Sand & $\alpha$ & 0.92 \\
\hline$(\mathrm{P}) \mathrm{z}$ & Aver. Pressure & SILTY & $\alpha$ & 0.94 \\
\hline$(\mathrm{S}) \mathrm{z}$ & \multicolumn{4}{|l|}{ Aver. Stress } \\
\hline$(A z)$ & \multicolumn{4}{|c|}{ Orbital Acceleration $\mathrm{Az}=\mathrm{A} 0(\varepsilon \zeta / \varepsilon 0)$} \\
\hline (pc) & \multicolumn{4}{|l|}{ Circular frequency } \\
\hline (Vz) & \multicolumn{4}{|l|}{ Orbital velocity } \\
\hline & \multicolumn{4}{|c|}{ SEISMIC PORE WATER PRESSURE } \\
\hline
\end{tabular}

SURFACE ORBITAL L ACL

$\begin{array}{ll}\mathrm{A} 0= & 1.50 \mathrm{M} / \mathrm{s}^{2} \\ (\mathrm{C}) 0= & 81.80 \mathrm{M} / \mathrm{s}\end{array}$

$T=1.968 \mathrm{sec} \quad \mathrm{FC}=3.192 \mathrm{rad} \quad\left(\mathrm{V}_{0}\right)=0.470 \mathrm{M} / \mathrm{sec}$

(ع) 0.00574 ORBITAL STRAIN

SURFACE CELERITY

\begin{tabular}{|c|c|c|c|c|c|c|c|c|c|c|c|c|c|c|c|c|c|c|c|c|}
\hline \multirow[t]{3}{*}{ SOIL } & $z$ & d & $\sigma \varepsilon 0$ & $\omega$ & $\mu$ & $\rho$ & $v$ & c & $a(v)$ & $\mathrm{Bcx}$ & $1 / M$ & $r$ & rd & sum & STRAIN & Pz & spwp & (S)z & Acc & DEPL. \\
\hline & & m & $T / m^{2}$ & $\%$ & $T / m^{2}$ & mass & nu & $\mathrm{m} / \mathrm{sec}$ & - & - & Ton $/ \mathrm{m}^{2}$ & $1 / m$ & - & - & - & $\mathrm{T} / \mathrm{m}^{2}$ & $\mathrm{~T} / \mathrm{m}^{2}$ & $\mathrm{~T} / \mathrm{m}^{2}$ & $\mathrm{~m} / \mathrm{s}^{2}$ & $\mathrm{~cm}$ \\
\hline & 0.00 & 0.00 & 0.00 & 0.00 & 1030.00 & 0.136 & 0.25 & 81.80 & 0.85 & 0.80 & 2426.95 & 0.0332 & 0.0000 & 0.0000 & 0.005744 & 13.941 & & 13.941 & 15.00 & 14.72 \\
\hline A1 & 1.00 & 1.00 & 1.80 & 50.00 & 1030.00 & 0.136 & 0.25 & 81.80 & 0.85 & 0.80 & 2426.95 & 0.0332 & 0.0332 & 0.0332 & 0.005557 & 13.486 & & 13.486 & 14.51 & 14.24 \\
\hline SWT & 3.00 & 2.00 & 5.40 & 50.00 & 1030.00 & 0.136 & 0.25 & 81.80 & 0.85 & 0.80 & 2426.95 & 0.0332 & 0.0663 & 0.0995 & 0.005200 & 12.621 & & 12.621 & 13.58 & 13.33 \\
\hline A2 & 6.00 & 3.00 & 6.00 & 125.00 & 380.00 & 0.136 & 0.25 & 49.69 & 0.85 & 0.80 & 895.38 & 0.0546 & 0.1638 & 0.2634 & 0.004414 & 3.953 & 2.196 & 1.757 & 11.53 & 11.31 \\
\hline B1 & 8.50 & 2.50 & 7.50 & 300.00 & 230.00 & 0.144 & 0.35 & 37.57 & 0.90 & 0.90 & 625.32 & 0.0765 & 0.1912 & 0.4545 & 0.003646 & 2.280 & 1.200 & 1.080 & 9.52 & 9.34 \\
\hline B2 & 11.50 & 3.00 & 9.00 & 300.00 & 230.00 & 0.141 & 0.35 & 37.96 & 0.90 & 0.90 & 625.32 & 0.0757 & 0.2270 & 0.6815 & 0.002906 & 1.817 & 0.956 & 0.861 & 7.59 & 7.45 \\
\hline c & 15.00 & 3.50 & 13.70 & 225.00 & 397.00 & 0.131 & 0.35 & 51.75 & 0.90 & 0.90 & 1079.35 & 0.0555 & 0.1943 & 0.8759 & 0.002393 & 2.582 & 1.359 & 1.223 & 6.25 & 6.13 \\
\hline D & 18.00 & 3.00 & 18.00 & 100.00 & 600.00 & 0.116 & 0.35 & 67.60 & 0.90 & 0.90 & 1631.26 & 0.0425 & 0.1275 & 1.0033 & 0.002105 & 3.436 & 1.808 & 1.627 & 5.50 & 5.40 \\
\hline $\mathrm{E}$ & 21.00 & 3.00 & 21.50 & 225.00 & 850.00 & 0.114 & 0.35 & 81.17 & 0.90 & 0.90 & 2310.95 & 0.0354 & 0.1062 & 1.1095 & 0.001894 & 4.377 & 2.304 & 2.073 & 4.95 & 4.85 \\
\hline $\mathrm{F}$ & 24.00 & 3.00 & 25.00 & 50.00 & 1500.00 & 0.180 & 0.25 & 85.81 & 0.85 & 0.80 & 3534.40 & 0.0316 & 0.0949 & 1.2044 & 0.001723 & 6.088 & 3.382 & 2.706 & 4.50 & 4.41 \\
\hline G & 26.00 & 2.00 & 27.75 & 250.00 & 1047.00 & 0.110 & 0.35 & 91.71 & 0.90 & 0.90 & 2846.55 & 0.0313 & 0.0627 & 1.2670 & 0.001618 & 4.606 & 2.424 & 2.182 & 4.23 & 4.15 \\
\hline $\mathrm{H}$ & 31.00 & 5.00 & 29.00 & 45.00 & 1740.00 & 0.200 & 0.25 & 87.68 & 0.85 & 0.80 & 4099.90 & 0.0309 & 0.1547 & 1.4218 & 0.001386 & 5.683 & 3.157 & 2.526 & 3.62 & 3.55 \\
\hline \multirow[t]{2}{*}{1} & 35.00 & 4.00 & 31.00 & 120.00 & 1130.00 & 0.110 & 0.35 & 95.27 & 0.90 & 0.90 & 3072.21 & 0.0302 & 0.1206 & 1.5424 & 0.001229 & 3.774 & 1.987 & 1.788 & 3.21 & 3.15 \\
\hline & & 35.00 & & & & & & & & & & & & & & & & & & \\
\hline
\end{tabular}

SURFACE WAVE LAYERED SUBSOIL

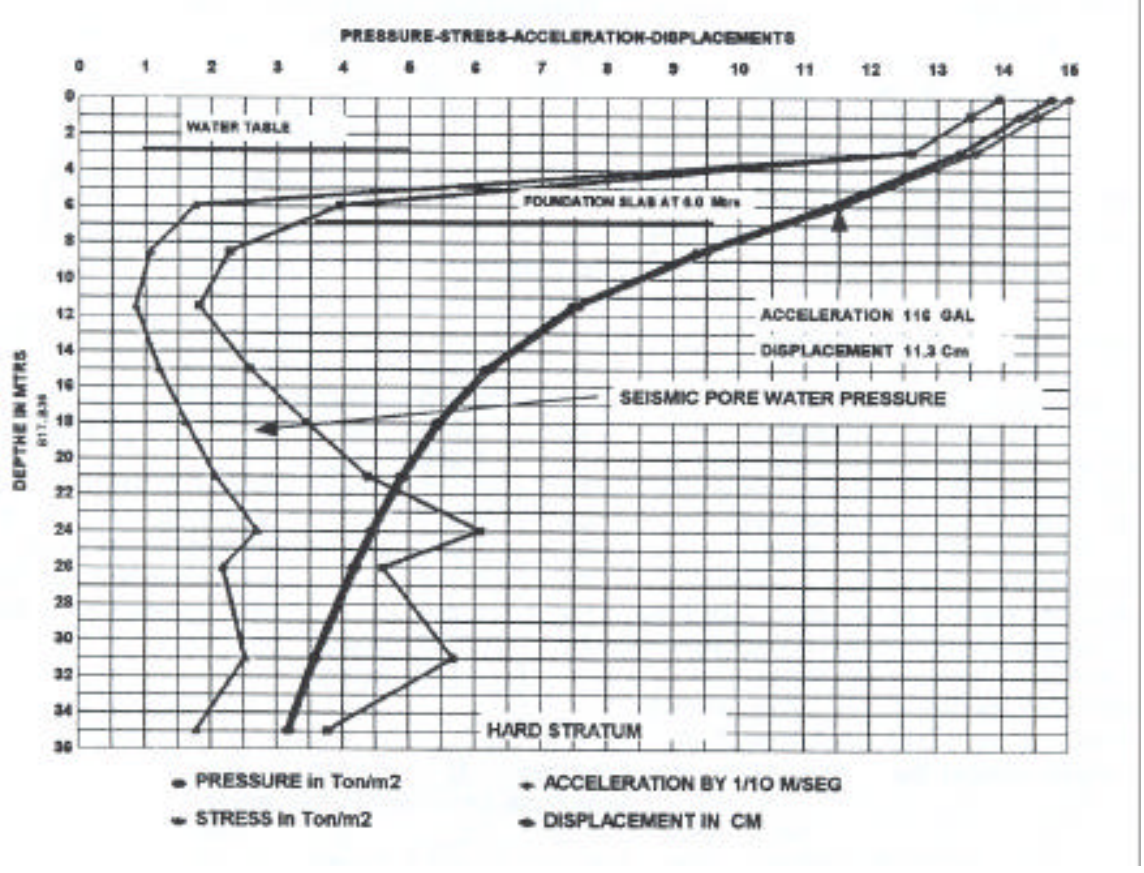

CALCULATION SHEET 3a 
COMPESATED FOUNDATION. “ISES5IN" SEISM
FLEXIBILITY OF THE STRATIFY SOIL MASS IN
THE FOUNDATION SYMMETRY AXIS
STRIPE 2B/2=

COORDENATE X IN CM.
D-20

$\mathrm{CHI}=2$

$200 \mathrm{~cm}$

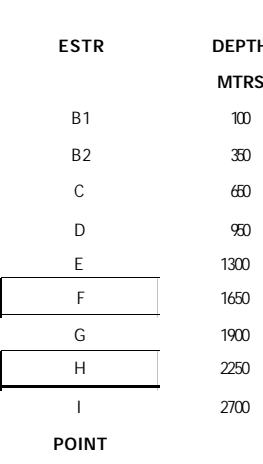

$\begin{array}{ccc}\begin{array}{ccc}\text { ESTR } \\ \text { H-cm }\end{array} & \alpha & \text { (PSI)1 } \\ 200 & 1.488 & 0.785 \\ 300 & 1.287 & 0.278 \\ 350 & 1.074 & 0.153 \\ 300 & 0.901 & 0.105 \\ 300 & 0.745 & 0.077 \\ 300 & 0.629 & 0.061 \\ 200 & 0.563 & 0.053 \\ 500 & 0.490 & 0.044 \\ 400 & 0.418 & 0.037 \\ \text { FLEXIBILITY c } & \text { 3 } \mathbf{k g} & \end{array}$
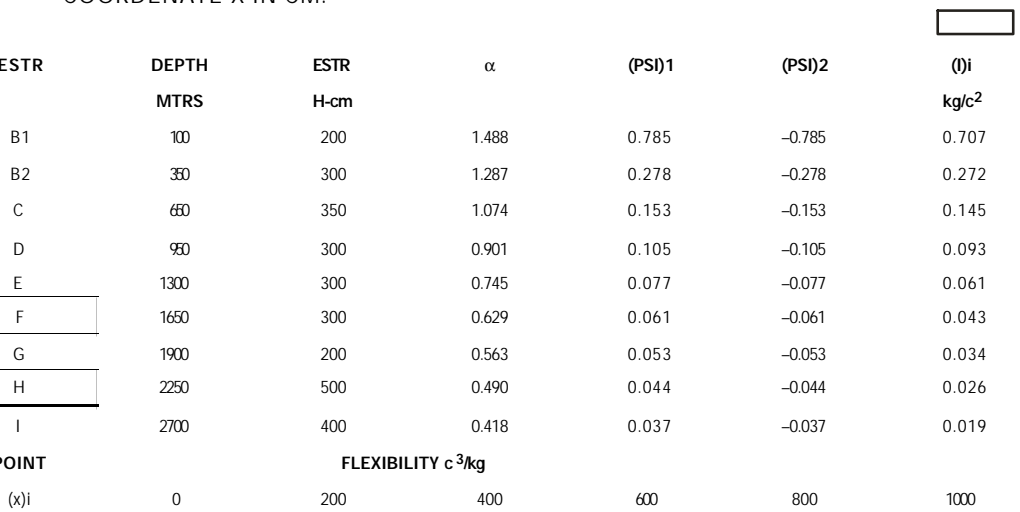

LEXIBILITY c ${ }^{3} / \mathrm{kg}$

\begin{tabular}{|c|c|c|c|}
\hline & 0 & 200 & 400 \\
\hline$(x) i$ & $\mathrm{C} 1$ & $C-2$ & $c-3$ \\
\hline$a$ & 4.428 & 2.042 & 1.038 \\
\hline C- 2 & 2.042 & 4.428 & 2.042 \\
\hline$C-3$ & 1.038 & 2.042 & 4.428 \\
\hline$C-4$ & 0.618 & 1.038 & 2.042 \\
\hline C- 5 & 0.399 & 0.618 & 1.038 \\
\hline$C-6$ & 0.273 & 0.399 & 0.618 \\
\hline \multicolumn{4}{|c|}{ INVERTED MATRIX } \\
\hline & $\mathrm{C} 1$ & C- 2 & $c-3$ \\
\hline a & 0.290 & -0.126 & 0.002 \\
\hline C-2 & -0.126 & 0.350 & 0.125 \\
\hline C. & 0.002 & -0.125 & \\
\hline
\end{tabular}

600

800

C-4 C-5

$c-5$

$0.618 \quad 0.399$

\begin{tabular}{l|l|l}
2.042 & 1.038 & 0.618 \\
4.428 & 2.042 & 1.038
\end{tabular}

$$
0.273
$$$$
0.399
$$$$
0.618
$$

1.038

$\begin{array}{ll}4.428 & 2.042\end{array}$

$2.042 \quad 1.038$

$$
0.618
$$$$
2.042
$$

$\mathrm{Kg} / \mathrm{C}^{3}$

\begin{tabular}{|l|l|}
\hline 4.428 & 2.042 \\
\hline 2.042 & 4.428 \\
\hline
\end{tabular}

$\mu$
$\mathbf{k g} / \mathbf{c m}^{2}$
23.00
23.00
39.70
60.00
85.00
150.00
104.70
174.00
113.00

\begin{tabular}{ccc|}
$v$ & $\begin{array}{c}\text { (Alpha) } \\
\mathbf{c}^{\mathbf{3} / \mathbf{k G}}\end{array}$ & $\begin{array}{c}\text { Displ.. } \\
\text { corregido }\end{array}$ \\
0.350 & 3.221 & 2.278 \\
0.350 & 4.831 & 1.315 \\
0.350 & 3.265 & 0.472 \\
0.350 & 1.852 & 0.171 \\
0.350 & 1.307 & 0.079 \\
0.250 & 0.800 & 0.034 \\
0.350 & 0.707 & 0.024 \\
0.250 & 1.149 & 0.029 \\
0.350 & 1.311 & 0.024 \\
\hline & SUM & $\mathbf{4 . 4 2 8}$ \\
\hline
\end{tabular}

'ANTI-SYMETRIC REDUCED MATRIX

$\begin{array}{ccc}\text { C1 } & \text { C-2 } & \text { C-3 } \\ 4.155 & 1.643 & 0.420 \\ 1.643 & 3.810 & 1.004 \\ 0.420 & 1.004 & 2.386\end{array}$

SPRING CONSTANT FOR BASE ROTATION

SPRING CONSTANT FOR WALL ROTATION

$K w=(1+v) d^{\wedge} 2 *(1) * u$

TOTAL CONSTANT

TRANSVERSAL CONFIGURATION

$\begin{array}{ccc}\mathbf{C m} & \mathbf{K g} / \mathbf{c}^{\mathbf{2}} \mathbf{r d} & \text { Ton } / \mathbf{m}^{2} / \mathbf{r d} \\ \mathbf{d i} & \mathbf{q} / \mathbf{0} & \mathbf{X i} / \mathbf{1 0} \\ 500 & 107.58 & 1075.78 \\ 300 & 29.57 & 295.74 \\ 100 & 10.53 & 105.30\end{array}$



\begin{tabular}{|c|c|}
\hline & 6371.43 \\
\hline $\mathrm{Kb}=$ & 25486 \\
\hline$K \mathbf{w}=$ & 42185 \\
\hline$K b+K w=$ & 67671 \\
\hline
\end{tabular}

$1.00-105.30$

OVERTURNING M.

Ovt $=((\mathbf{K b}+\mathbf{K w}) \theta$

MASS CENTER

MASS PER LINEAL METER

FOUNDATION PERIOD OF ROTATION

BUILDING PERIOD FROM CALCULATION SHEET 7

COUPLED PERIOD OF THE BUILDING STRUCTURE

CRITICAL DAMPING OF THE SOIL DEPOSIT

CRITICAL DAMPING OF THE STRUCTURE

EQUIVALENT CRITICAL DAMPING, REF 8

ACCELERATION FACTOR AT THE CENTER MASS

ACCELERATION ASIGNED AT THE GROUND SURFACE

ACCELERATION AT 6.0 METROS DEPTH

ACC. CENTER OF MASS

OVERTURNING MOMENT OSt

1.694

$M \operatorname{trs} / \mathrm{s}$

MASA*Acc.*hc

OVERTURNING MOMENT Ost $258.481 \quad$ TOn $/ \mathrm{m} / \mathrm{m} \quad$ ROTATION $\quad \theta=\mathbf{0 . 0 0 3 8 2}$ rad

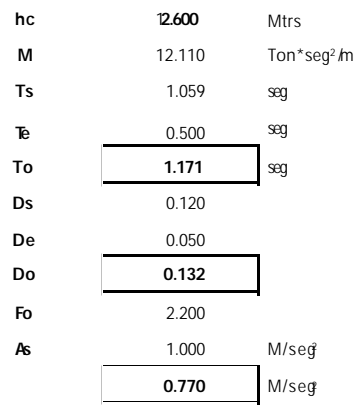

REACTIONS OF SEISMIC OVERTURNING

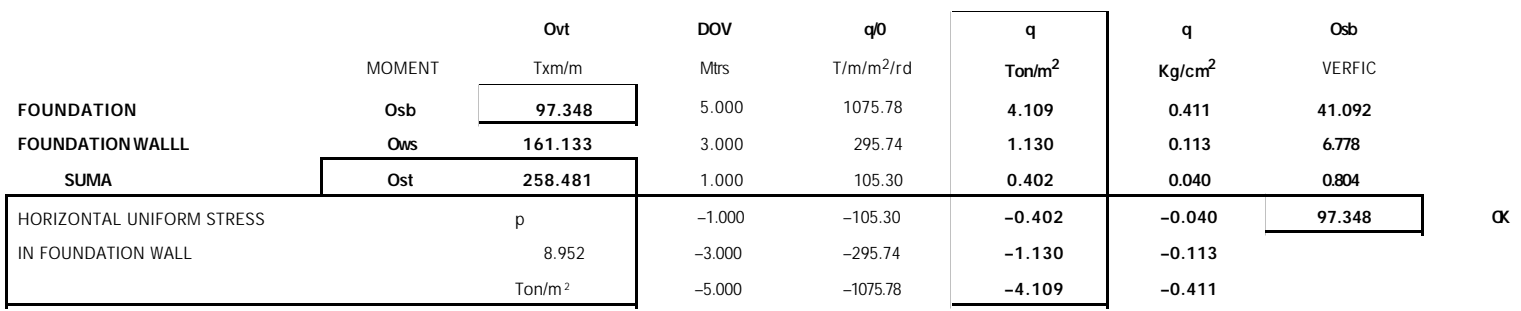

\section{CALCULATION SHEET 4}




\section{CALCOR31 D-22}

\section{CALCULATION OF THE SHEAR FORCES IN THE BUILDING FLOORS}

\section{BUILDING WITH SIX FLOORS}

\section{BASEMENT AND RIGID BOX TYPE FOUNDATION} CALCULATION OF THE SURFACE SEISMIC WAVE AND ROCKING ANALISIS

\begin{tabular}{|c|c|c|c|c|c|c|c|c|c|c|c|c|c|c|}
\hline \multicolumn{15}{|c|}{ FROM CALCULATION SHEET 3 IS OBTAINED } \\
\hline \multicolumn{10}{|c|}{ Acceleration at the base of the foundation, SHEET 3} & \multicolumn{2}{|l|}{77.00} & \multicolumn{3}{|l|}{ GAL } \\
\hline \multicolumn{10}{|c|}{ Acceleration at the center of mass, SHEET 4} & \multicolumn{2}{|l|}{1.694} & \multicolumn{3}{|c|}{$\mathrm{m} / \mathrm{sec}$} \\
\hline \multicolumn{10}{|c|}{ Displacement at the foundation grade elevation, SHEET 3} & \multicolumn{2}{|l|}{0.0754} & \multicolumn{3}{|l|}{ M } \\
\hline \multicolumn{10}{|c|}{ Rotation of the foundation, SHEET 4} & \multicolumn{2}{|l|}{0.00382} & \multicolumn{3}{|l|}{ RAD } \\
\hline \multicolumn{10}{|c|}{ Foundation rocking period, SHEET 4} & \multicolumn{2}{|l|}{1.059} & \multicolumn{3}{|l|}{ Seg } \\
\hline \multicolumn{10}{|c|}{ Subsoil period, SHEET 3} & \multicolumn{2}{|l|}{1.964} & \multicolumn{3}{|l|}{ Seg } \\
\hline \multicolumn{10}{|c|}{ Periodo acoplado estructura - cimentacion- subsuelo } & \multicolumn{2}{|l|}{2.231} & \multicolumn{3}{|l|}{ Seg } \\
\hline \multicolumn{10}{|c|}{ System circular frequency } & \multicolumn{2}{|l|}{2.816} & $1 / \mathrm{sec}$ & & \\
\hline Base she & , SHEET & & & & & & & & & 20.51 & & Ton & & \\
\hline Accelerat & on in the & or levels & & & & & & & & $(A C)$ & & & & \\
\hline FROM & CALCU & ATION & SHEE & $1, \mathrm{ISOE}$ & BTAINE & & & & & & & & & \\
\hline Mass per & rame an & floor & & & & & & & & 1.346 & & $\mathrm{~T}^{*} \mathrm{~s}^{\wedge}$ & $2 / m$ & \\
\hline Mass per & rame anc & ground flo & & & & & & & & 1.590 & & $\mathrm{~T}^{*} \mathrm{~s}^{\wedge}$ & $2 / m$ & \\
\hline Mass of $t$ & e founda & & & & & & & & & 2.446 & & $\mathrm{~T}^{*} \mathrm{~s}^{\wedge}$ & $2 / m$ & \\
\hline Mass of $t$ & e founda & on and ac & ded the o & round floor & & & & & & 4.037 & & $\mathrm{~T}^{*} \mathrm{~s}^{\wedge}$ & $2 / m$ & \\
\hline Total ma & total ea & $d$ foundat & on / ML & & & & & & & 12.11 & & $T^{*} \mathrm{~s}^{\wedge}$ & $2 / m$ & \\
\hline Height of & center of & nass & & & & & & & & 12.66 & & Mtrs & & \\
\hline Structura & flexibility & er floor a & $d$ frame & or all the flo & oor levels & & & & & $1 \mathrm{~K}$ & & $\mathrm{~m} / \mathrm{To}$ & & \\
\hline$\delta$ & Displac & nent beca & se or fou & ndation vert & tical rotat & & & & & column 4 & & & & \\
\hline$\Delta 2$ & Displac & nent beca & se of flex & ure induced & by the fo & ndation r & ation & & & column 7 & & & & \\
\hline$\Sigma \Delta=\delta+\Delta$ & & & & & & & & & & & & & & \\
\hline 1 & 2 & 3 & 4 & 5 & 6 & 7 & 8 & 9 & 10 & 11 & 12 & 13 & 14 & 15 \\
\hline FLOOR & $\mathrm{h}$ & MASS & ESPL. & $1 / K$ & DISPL. & DISPL. & DISPL. & $(A c)$ & $(\mathrm{Ac})$ & SHEAR & SUM & SECTION & $\Delta$ & SUM \\
\hline & & $\mathrm{PIS} / \mathrm{ml}$ & $\delta$ & FLOOR & $\Delta 1$ & $\Delta 2$ & $\Sigma \Delta$ & FLOOR & DAES & FLOOR & CORT. & $d$ & MOM. & MOM. \\
\hline FLOOR & Mtrs & $T * s^{2} / m$ & MTRS & $\mathrm{m} /$ Ton & Mtrs & Mtrs & $4+7$ & $M / s^{2}$ & $\mathrm{M} / \mathrm{s}^{2}$ & Ton/m & Ton/m & Mtrs & Ton $\mathrm{xm}$ & Ton $\mathrm{xm}$ \\
\hline 6 & 25.50 & 1.346 & 0.173 & $4.00 \mathrm{E}-04$ & 0.00124 & 0.00494 & 1.1778 & 1.409 & 2.301 & 3.097 & 3.097 & 3.20 & 9.910 & 9.91 \\
\hline 5 & 22.30 & 1.346 & 0.161 & $4.00 \mathrm{E}-04$ & 0.00115 & 0.00370 & 0.1643 & 1.302 & 2.128 & 2.864 & 5.961 & 3.20 & 19.075 & 28.98 \\
\hline 4 & 19.10 & 1.346 & 0.148 & $2.86 \mathrm{E}-04$ & 0.00075 & 0.00256 & 0.1509 & 1.197 & 1.955 & 2.631 & 8.592 & 3.20 & 27.494 & 56.48 \\
\hline 3 & 15.90 & 1.346 & 0.136 & $2.86 \mathrm{E}-04$ & 0.00069 & 0.00181 & 0.1379 & 1.094 & 1.787 & 2.405 & 10.997 & 3.20 & 35.189 & 91.67 \\
\hline 2 & 12.70 & 1.346 & 0.124 & $1.82 \mathrm{E}-04$ & 0.00040 & 0.00112 & 0.1250 & 0.991 & 1.620 & 2.180 & 13.177 & 3.20 & 42.165 & 133.83 \\
\hline 1 & 9.50 & 1.346 & 0.112 & $1.82 \mathrm{E}-04$ & 0.00036 & 0.00072 & 0.1124 & 0.891 & 1.456 & 1.960 & 15.136 & 3.50 & 52.977 & 186.81 \\
\hline PB & 6.00 & 1.590 & 0.098 & $1.82 \mathrm{E}-04$ & 0.00037 & 0.00037 & 0.0987 & 0.783 & 1.279 & 2.033 & 17.170 & 4.00 & 68.678 & 255.49 \\
\hline $\mathrm{CIM}$ & 1.00 & 2.446 & 0.079 & & 0.00000 & 0.00000 & 0.0792 & 0.628 & 1.027 & 2.511 & 19.680 & 2.00 & 39.361 & 294.85 \\
\hline BASE & 0.00 & & 0.075 & & & & 0.0754 & 0.598 & 0.977 & 0.000 & 19.680 & & & 294.85 \\
\hline TOTA & MASS & 12.11 & & & & & & 1.037 & 1.694 & 19.680 & SUM & SUM & 294.85 & \\
\hline
\end{tabular}

\section{CALCULATION SHEET 5a}




\section{CALCOR3E D-22}

\section{CALCULATION OF THE SHEAR FORCES IN THE BUILDING FLOORS}

\section{BUILDING WITH SIX FLOORS \\ BASEMENT AND RIGID BOX TYPE FOUNDATION CALCULATION OF THE SURFACE SEISMIC WAVE AND ROCKING ANALISIS}

\author{
FROM CALCULATION SHEET 3 IS OBTAINED \\ Acceleration at the base of the foundation, SHEET 3 \\ Acceleration at the center of mass, SHEET 4 \\ Displacement at the foundation grade elevation SHEET 3 \\ Rotation of the foundation, SHEET 4 \\ Foundation structure period, SHEET 4 \\ Subsoil period, SHEET 3 \\ Couppled period structure subsoil foundation \\ System circular frequency \\ Base shear, SHEET 4 \\ Acceleration in the floor levels \\ FROM CALCULATION SHEET 1, IS OBTAINED
}

$\begin{array}{ll}1.346 & \mathrm{~T}^{*} \mathrm{~s}^{\wedge} 2 / \mathrm{m} \\ 1.590 & \mathrm{~T}^{*} \mathrm{~s}^{\wedge} 2 / \mathrm{m} \\ 2.446 & \mathrm{~T}^{*} \mathrm{~s}^{\wedge} 2 / \mathrm{m} \\ 4.037 & \mathrm{~T}^{*} \mathrm{~s}^{\wedge} 2 / \mathrm{m} \\ 12.11 & \mathrm{~T}^{*} \mathrm{~s}^{\wedge} 2 / \mathrm{m} \\ 12.66 & \mathrm{Mtrs} \\ 1 \mathrm{~K} & \mathrm{~m} / \mathrm{Ton}\end{array}$

Column 4

Column 7

Column 8

$\Sigma \Delta=\delta+\Delta 2+\Delta 3$

\begin{tabular}{|c|c|c|c|c|c|c|c|c|c|c|c|c|c|c|c|}
\hline 1 & 2 & 3 & 4 & 5 & 6 & 7 & 8 & 9 & 10 & 11 & 12 & 13 & 14 & 15 & 16 \\
\hline \multirow[t]{2}{*}{ FLOOR } & h & \multicolumn{2}{|c|}{ MASS DEPL. } & $1 / K$ & DISPL. & DISPL. & DISPL. & DISPL. & (Ac) & (Ac) & SHEAR & SUM & SECTION & $\Delta$ & SUM \\
\hline & & $\mathrm{PIS} / \mathrm{ml}$ & $\delta$ & FLOOR & $\Delta \mathbf{1}$ & $\Delta 2$ & $\Delta 3$ & $\Sigma \Delta$ & FLOOR & DAES & FLOOR & CORT. & d & мом. & мом. \\
\hline FLOOR & Mtrs & $\mathbf{T} * \mathbf{s} 2 / \mathbf{m}$ & MTRS & $\mathrm{m} /$ Ton & Mtrs & Mtrs & Mtrs & $4+7+8$ & $M / \mathbf{s}^{2}$ & $M / s^{2}$ & Ton/m & Ton/m & Mtrs & Ton xm & Ton $\mathrm{xm}$ \\
\hline 6 & 25.50 & 1.346 & 0.174 & 4.00E-04 & 0.00135 & 0.00529 & 0.02230 & 0.2014 & 1.597 & 2.515 & 3.384 & 3.384 & 3.20 & 10.830 & 10.83 \\
\hline 5 & 22.30 & 1.346 & 0.162 & 4.00E-04 & 0.00125 & 0.00393 & 0.02040 & 0.1859 & 1.474 & 2.322 & 3.124 & 6.509 & 3.20 & 20.828 & 31.66 \\
\hline 4 & 19.10 & 1.346 & 0.149 & $2.86 \mathrm{E}-04$ & 0.00081 & 0.00269 & 0.01680 & 0.1688 & 1.339 & 2.109 & 2.837 & 9.346 & 3.20 & 29.908 & 61.57 \\
\hline 3 & 15.90 & 1.346 & 0.137 & $2.86 \mathrm{E}-04$ & 0.00073 & 0.00187 & 0.01320 & 0.1522 & 1.207 & 1.901 & 2.558 & 11.904 & 3.20 & 38.093 & 99.66 \\
\hline 2 & 12.70 & 1.346 & 0.125 & $1.82 \mathrm{E}-04$ & 0.00041 & 0.00114 & 0.00880 & 0.1349 & 1.069 & 1.684 & 2.266 & 14.170 & 3.20 & 45.345 & 145.00 \\
\hline 1 & 9.50 & 1.346 & 0.113 & $1.82 \mathrm{E}-04$ & 0.00036 & 0.00073 & 0.00560 & 0.1190 & 0.944 & 1.486 & 2.000 & 16.170 & 3.50 & 56.596 & 201.60 \\
\hline PB & 6.00 & 1.590 & 0.099 & $1.82 \mathrm{E}-04$ & 0.00037 & 0.00037 & 0.00220 & 0.1019 & 0.808 & 1.272 & 2.023 & 18.194 & 4.00 & 72.774 & 274.37 \\
\hline CIM & 1.00 & 2.446 & 0.080 & & 0.00000 & 0.00000 & 0.00000 & 0.0802 & 0.636 & 1.002 & 2.451 & 20.644 & 2.00 & 41.288 & 315.66 \\
\hline BASE & 0.00 & & 0.076 & & & & & 0.0764 & 0.606 & 0.954 & 0.000 & 20.644 & & & 315.66 \\
\hline TOTAL $\mathrm{N}$ & MASS & 12.11 & & & & & & MEDIA & 1.076 & 1.694 & 20.644 & SUM & SUM & 315.66 & \\
\hline $\begin{array}{l}\text { Relative } \\
\text { Added wit }\end{array}$ & $\begin{array}{l}\text { lisplac } \\
\text { th the }\end{array}$ & rsiona & pin & te neac & & & & & $\begin{array}{l}2.759 \mathrm{~cm} \\
4.00 \mathrm{~cm}\end{array}$ & & & & & & \\
\hline
\end{tabular}

\section{CALCULATION SHEET 5b}


TOREDIFE D-22

\section{TORSIONAL WHIPPING IN THE UPPER FLOORS}

(Shear n)

Shear per floor and meter symmetrical case
((SHEARn))X TORSIONAL 'SHEAR / METER AT A DISTANCE (x) FROM THE ROTATION CENTER $(\mathrm{x}) \quad(($ Shear $\mathrm{n})) \mathrm{X}($ shear $\mathrm{n}) *(1=0.45 \mathrm{X} / \mathrm{L})$ Coordenate from the torsion center
Tn Torsion per floor level $\quad T n=2 *($ Shear $n) *(0.45) L x L / 3$

$12 \mathrm{Mtrs}$. One half lenght of building

Factor $\left(1+0.45^{*} x / L\right)$

$\begin{array}{cccc} & \begin{array}{c}\text { SHEET } 5 b \\ \text { SUM }\end{array} & \begin{array}{c}\text { HEAD-FRAME } \\ \text { FOR TOR. }\end{array} & \begin{array}{c}\text { MOMENT } \\ \text { TORSION }\end{array} \\ \text { FLOOR } & \begin{array}{c}\text { (SHEARn) } \\ \text { TON / ML }\end{array} & \begin{array}{c}\text { PER FLOOR } \\ \text { TON / ML }\end{array} & \begin{array}{c}\text { PER FLOOR } \\ \text { TON } \times \text { M }\end{array} \\ & 3.384 & 4.907 & 133.19 \\ 6 & 6.509 & 9.438 & 256.19 \\ 5 & 9.346 & 13.552 & 367.86 \\ 4 & 11.904 & 17.261 & 468.54 \\ 3 & 14.170 & 20.547 & 557.73 \\ 2 & 16.170 & 23.447 & 636.45 \\ 1 & 18.194 & 26.381 & 716.12 \\ \text { PB } & & & \\ \text { CIM. } & & & \end{array}$

\section{SHEAR FORCES PER METER OF THE TORSIONAL WHIPPING ACTION IN THE SECTIONS AT THE INDICATED DISTANCES FROM THE ROTATION CENTER}

$\begin{array}{cccccc}\text { SECTIONS } & \text { CENTRO } & \mathrm{m} & \mathrm{m} & \mathrm{m} & \text { HEAD FRAME } \\ \text { DISTANCE } & 0.00 & 2 & 6 & 10 & 12 \mathrm{~m} \\ \text { FACTOR } & 1.000 & 1.075 & 1.225 & 1.375 & 1.450 \\ & ((\mathrm{CORTn})) \times & ((\mathrm{CORTn})) \mathrm{X} & ((\mathrm{CORTn})) \times & ((\mathrm{CORTn})) \times & ((\mathrm{CORTn})) \mathrm{X} \\ \text { EN PISO } & \text { TON/ML } & \text { TON/ML } & \text { TON/ML } & \text { TON/ML } & \text { TON/ML } \\ 6 & 3.384 & 3.64 & 4.15 & 4.65 & 4.91 \\ 5 & 6.509 & 7.00 & 7.97 & 8.95 & 9.44 \\ 4 & 9.346 & 10.05 & 11.45 & 12.85 & 13.55 \\ 3 & 11.904 & 12.80 & 14.58 & 16.37 & 17.26 \\ 2 & 14.170 & 15.23 & 17.36 & 19.48 & 20.55 \\ 1 & 16.170 & 17.38 & 19.81 & 22.23 & 23.45 \\ \text { PB } & 18.194 & 19.56 & 22.29 & 25.02 & 26.38 \\ \text { CIM. } & & & & & \end{array}$

\section{CALCULATION SHEET 6}


PERIDIFE D-22

\section{CALCULATION OF THE AVERAGE CELERITY AND FUNDAMENTAL PERIOD OF THE BUILDING STRUCTURE}

\begin{tabular}{|c|c|c|c|c|c|}
\hline \multicolumn{3}{|c|}{$\begin{array}{l}\text { Height between floors } \\
\text { Width } \quad 12.00 \mathrm{M} \\
\text { Lenght } \quad 24.00 \mathrm{M} \\
\text { Altura de piso } \quad \mathrm{M} \\
\text { Period seg by the celerity method }\end{array}$} & \multicolumn{2}{|c|}{  } & \\
\hline Average celerity & & $\mathrm{Cm}$ & 188.93 & M/Seg & 0.4975 \\
\hline Period & & $\mathrm{Te}=$ & 0.4975 & Seg & \\
\hline Circular frequency & & \multirow[t]{2}{*}{$\mathrm{Fc}=$} & 12.629 & $1 /$ seg & \\
\hline OK with holzer & & & & & \\
\hline 1 & 2 & 3 & 4 & 5 & 6 \\
\hline \multirow[t]{2}{*}{ FLOOR } & z & $d$ & K & MASS/ & CELERITY \\
\hline & & M & Ton/m & FLOOR & Cs \\
\hline 6 & 23.50 & 3.20 & 2500.00 & 1.347 & 137.86 \\
\hline 5 & 20.30 & 3.20 & 2500.00 & 1.347 & 137.86 \\
\hline 4 & 17.10 & 3.20 & 3500.00 & 1.347 & 163.12 \\
\hline 3 & 13.90 & 3.20 & 3500.00 & 1.347 & 163.12 \\
\hline 2 & 10.70 & 3.20 & 5500.00 & 1.347 & 204.48 \\
\hline 1 & 7.50 & 3.50 & 5500.00 & 1.347 & 223.65 \\
\hline PB & 4.00 & 4.00 & 8500.00 & 1.590 & 292.44 \\
\hline CIM & 0.00 & 23.50 & AVERAC & CELERITY & 188.932 \\
\hline
\end{tabular}

SEE REF. 9, CAP. XII.3, PAG. 519

OK WITH HOLZER

\section{CALCULATION SHEET 7a}


HOLZERE D-23 D-30

\section{HOLZER MODAL METHOD}

$\delta \quad$ Floor displacement

$\Delta \delta \quad$ Decrement displacement

$f \quad$ Floor horizontal force $\quad\left(p^{\wedge} 2\right) * M(\delta-\Delta \delta)$

$\checkmark \quad$ Sum of flo or shear forces

K Floor rigidity

M Floormass

$\mathrm{T} \quad$ Building period $\quad 0.5002 \mathrm{seg}$

$p \quad$ Circular frequency $\quad 12.5611 / \mathrm{seg}$

$P^{\wedge} 2 \quad 157.791 / \mathrm{seg}^{\wedge} 2$ Average celerity $\quad 31.987 \mathrm{~m} / \mathrm{seg}$

\begin{tabular}{|c|c|c|c|c|c|c|c|c|c|c|}
\hline & & & & & & \multirow[b]{3}{*}{$\delta-\Delta \delta$} & & & \\
\hline & & & & & & & & \multicolumn{3}{|c|}{$\begin{array}{c}\text { REAL VALUES FROM } \\
\text { CALCULATION SHEET } 6\end{array}$} \\
\hline \multirow[t]{2}{*}{ FLOOR } & $d$ & K & $\mathrm{m}$ & $f$ & V & $\Delta \delta$ & & REAL & $A C$ & REAL \\
\hline & & Ton/m & Tsec/ $\mathrm{m}$ & Ton & Ton & $\mathrm{m}$ & $\mathrm{m}$ & $\delta$ & $\mathrm{m} / \mathrm{sec}^{2}$ & V \\
\hline 6 & 3.20 & 2500 & 1.347 & 212.54 & 212.5 & 0.085 & 1.000 & 0.0223 & 3.521 & 4.742 \\
\hline 5 & 3.20 & 2500 & 1.347 & 194.47 & 407 & 0.163 & 0.915 & 0.0204 & 3.221 & 4.339 \\
\hline 4 & 3.20 & 3500 & 1.347 & 159.87 & 566.9 & 0.162 & 0.752 & 0.0168 & 2.648 & 3.567 \\
\hline 3 & 3.20 & 3500 & 1.347 & 125.44 & 692.3 & 0.198 & 0.590 & 0.0132 & 2.078 & 2.799 \\
\hline 2 & 3.20 & 5500 & 1.347 & 83.40 & 775.7 & 0.141 & 0.392 & 0.0088 & 1.381 & 1.861 \\
\hline 1 & 3.50 & 5500 & 1.347 & 53.43 & 829.2 & 0.151 & 0.251 & 0.0056 & 0.885 & 1.192 \\
\hline \multirow[t]{2}{*}{ PB } & 4.00 & 8500 & 1.590 & 25.24 & 854.4 & 0.101 & 0.101 & 0.0022 & 0.354 & 0.563 \\
\hline & & & & & 829.2 & & & & & 18.500 \\
\hline
\end{tabular}

BASE SHEAR FROM CALCULATION SHEET $5 b$

CORRECTION FACTOR

$18.5 / 829.2$
18.500 Ton

0.0223

\section{CALCULATION SHEET 7b}


RIGIBC31 D-23

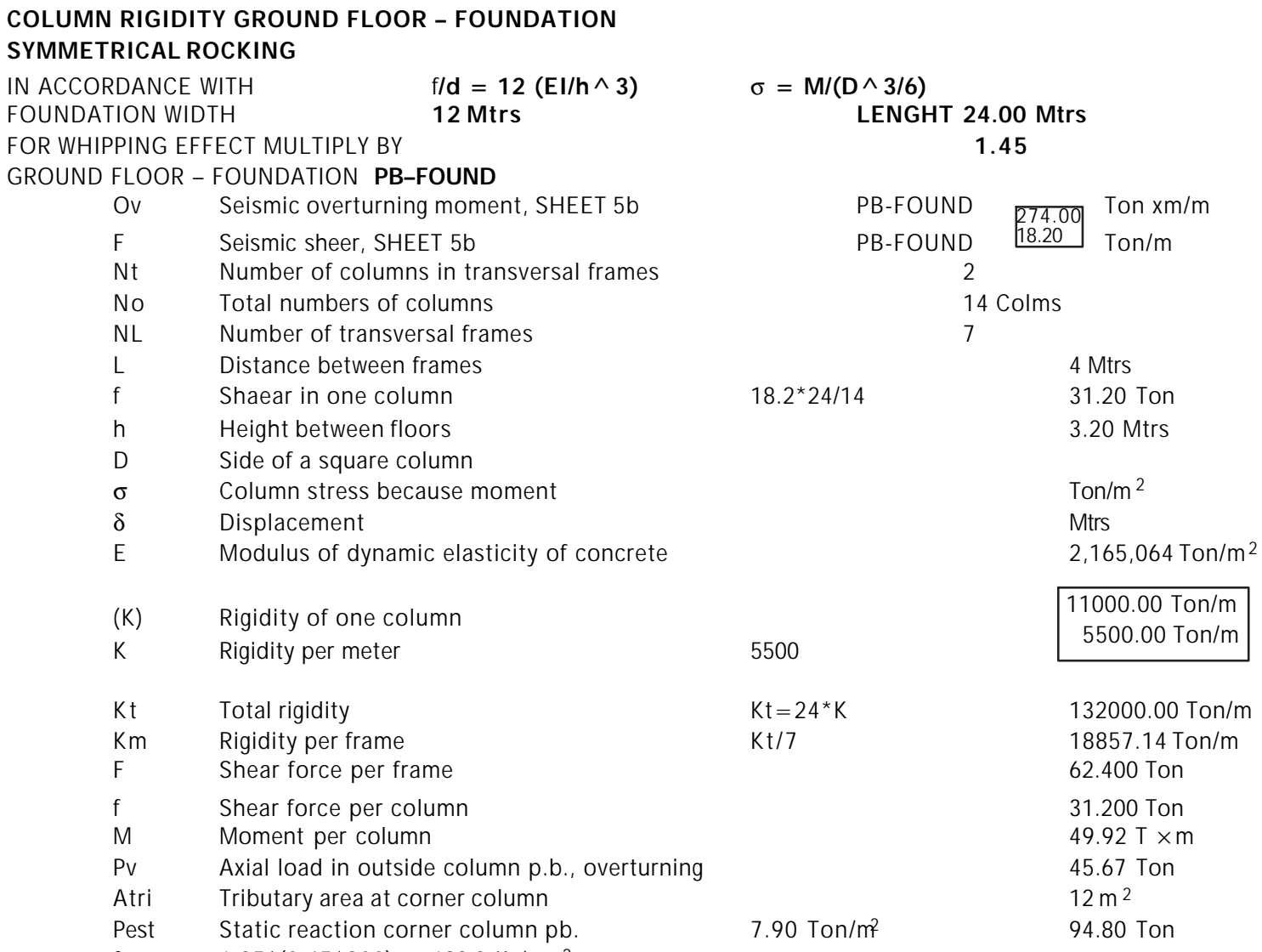

FLEXION STRESSES, AXIAL SEISMIC AND STATIC

\begin{tabular}{|c|c|c|c|c|c|c|c|c|c|c|c|c|}
\hline & & & & & & & & & AXIAL & AXIAL & & \\
\hline D & $\mathbf{h}$ & (K) & $K$ & D & Mc & $\mathbf{s}$ & $\sigma$ & $\sigma$ & OVERTUR. & $\sigma \varepsilon$ & $\sum \sigma$ & \\
\hline Mtrs & Mtrs & Ton $/ m^{\wedge} 2$ & Ton/M & Mtrs & Ton $\times m$ & $m^{\wedge} 3$ & Ton $/ m^{\wedge} 2$ & $\mathrm{Kg} / \mathrm{cm}^{\wedge} 2$ & $\mathrm{Kg} / \mathrm{cm}^{\wedge} 2$ & $\mathrm{Kg} / \mathrm{cm}^{\wedge} 2$ & & \\
\hline 0.40 & 3.20 & 1691 & 845.7 & 0.40 & 49.92 & 0.0107 & 4680.00 & 468.00 & 28.54 & 59.25 & 555.79 & \\
\hline 0.44 & 3.20 & 2476 & 1238 & 0.44 & 49.92 & 0.0142 & 3516.15 & 351.62 & 23.59 & 48.97 & 424.17 & \\
\hline 0.48 & 3.20 & 3507 & 1754 & 0.48 & 49.92 & 0.0184 & 2708.33 & 270.83 & 19.82 & 41.15 & 331.80 & \\
\hline 0.52 & 3.20 & 4831 & 2415 & 0.52 & 49.92 & 0.0234 & 2130.18 & 213.02 & 16.89 & 35.06 & 264.97 & \\
\hline 0.56 & 3.20 & 6498 & 3249 & 0.56 & 49.92 & 0.0293 & 1705.54 & 170.55 & 14.56 & 30.23 & 215.35 & \\
\hline 0.60 & 3.20 & 8563 & 4281 & 0.60 & 49.92 & 0.0360 & 1386.67 & 138.67 & 12.69 & 26.33 & 177.69 & \\
\hline 0.64 & 3.20 & 11085 & 5543 & 0.64 & 49.92 & 0.0437 & 1142.58 & 114.26 & 11.15 & 23.14 & 148.55 & PB-FOUNDATION \\
\hline 0.68 & 3.20 & 14127 & 7064 & 0.68 & 49.92 & 0.0524 & 952.57 & 95.26 & 9.88 & 20.50 & 125.64 & OK \\
\hline 0.72 & 3.20 & 17756 & 8878 & 0.72 & 49.92 & 0.0622 & 802.47 & 80.25 & 8.81 & 18.29 & 107.34 & \\
\hline 0.76 & 3.20 & 22043 & 11022 & 0.76 & 49.92 & 0.0732 & 682.32 & 68.23 & 7.91 & 16.41 & 92.55 & \\
\hline 0.80 & 3.20 & 27063 & 13532 & 0.80 & 49.92 & 0.0853 & 585.00 & 58.50 & 7.14 & 14.81 & 80.45 & \\
\hline 0.84 & 3.20 & 32896 & 16448 & 0.84 & 49.92 & 0.0988 & 505.34 & 50.53 & 6.47 & 13.44 & 70.44 & \\
\hline 0.88 & 3.20 & 39623 & 19812 & 0.88 & 49.92 & 0.1136 & 439.52 & 43.95 & 5.90 & 12.24 & 62.09 & \\
\hline 0.92 & 3.20 & 47334 & 23667 & 0.92 & 49.92 & 0.1298 & 384.65 & 38.46 & 5.40 & 11.20 & 55.06 & \\
\hline 0.96 & 3.20 & 56118 & 28059 & 0.96 & 49.92 & 0.1475 & 338.54 & 33.85 & 4.96 & 10.29 & 49.10 & \\
\hline 1.00 & 3.20 & 66072 & 33036 & 1.00 & 49.92 & 0.1667 & 299.52 & 29.95 & 4.57 & 9.48 & 44.00 & \\
\hline
\end{tabular}

CORRECTION OF RIDIDITIES ACCORDING TO ACCEPTABLE DISPLACEMENTS AND ALLOWABLE STRESSES

FOR TORTIONAL ROTATION THE HEAD-FRAME VALUES SHALL BE ADDED WITH 


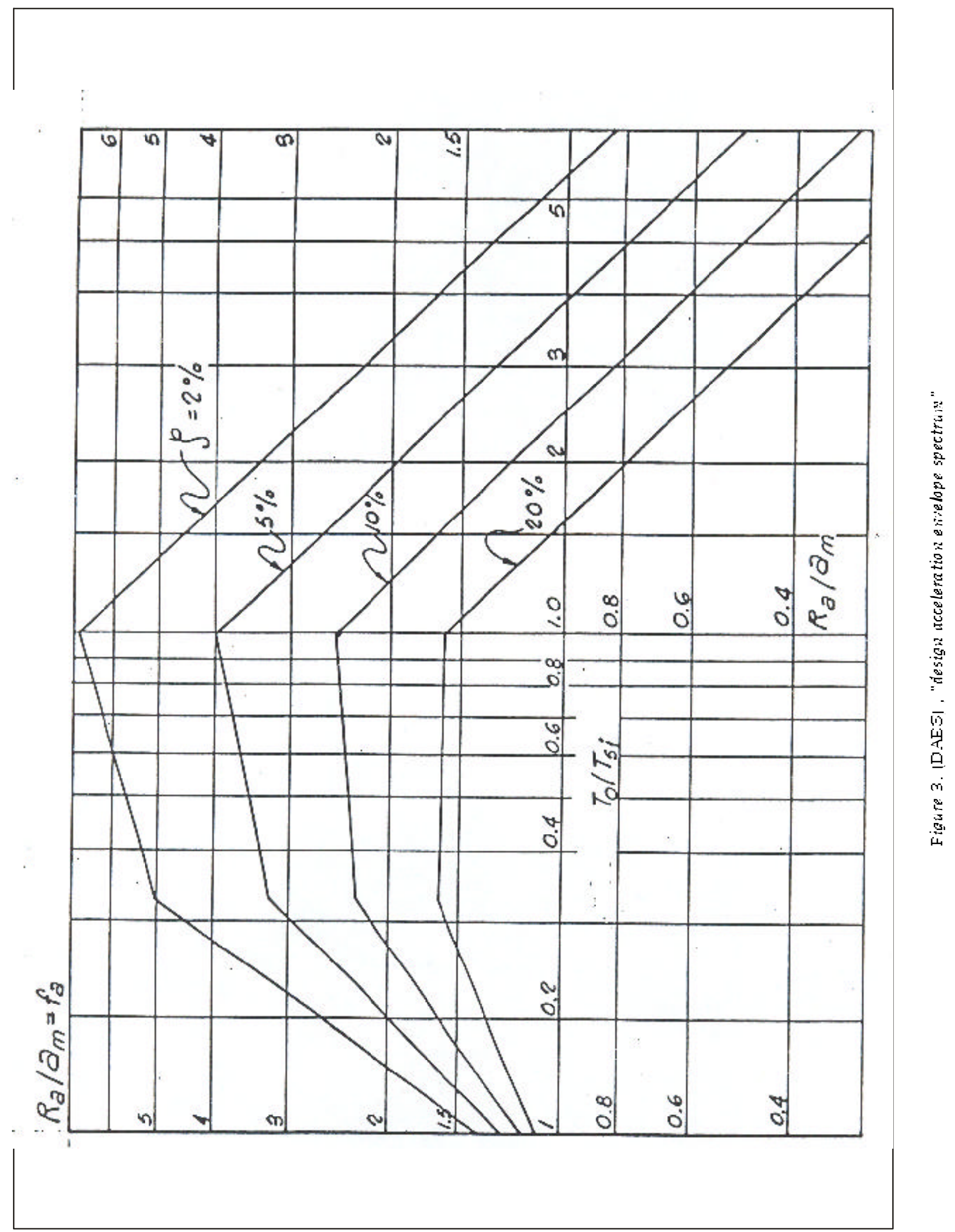


DOI:http://dx.doi.org/10.22201/fi.25940732e.2005.06n1.005

Acceleration in the Building Floors Using the Seismo-Geodynamic Theory
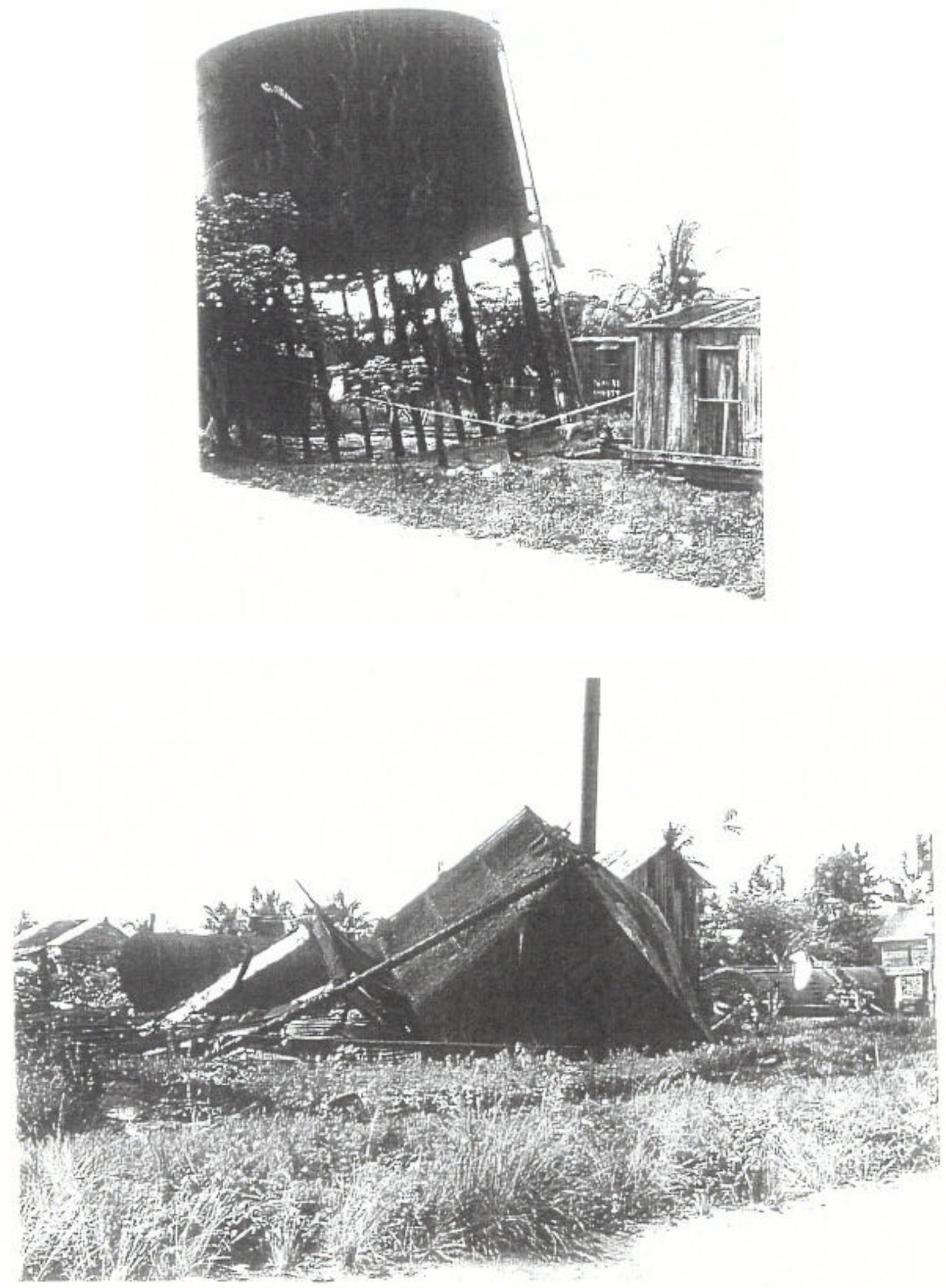

Photo 1. Reduc tion of the foun da tion bearing capacity and extru sion because of the seismic porewater pressure 
DOI:http://dx.doi.org/10.22201/fi.25940732e.2005.06n1.005

L. Zeevaert-Wiechers

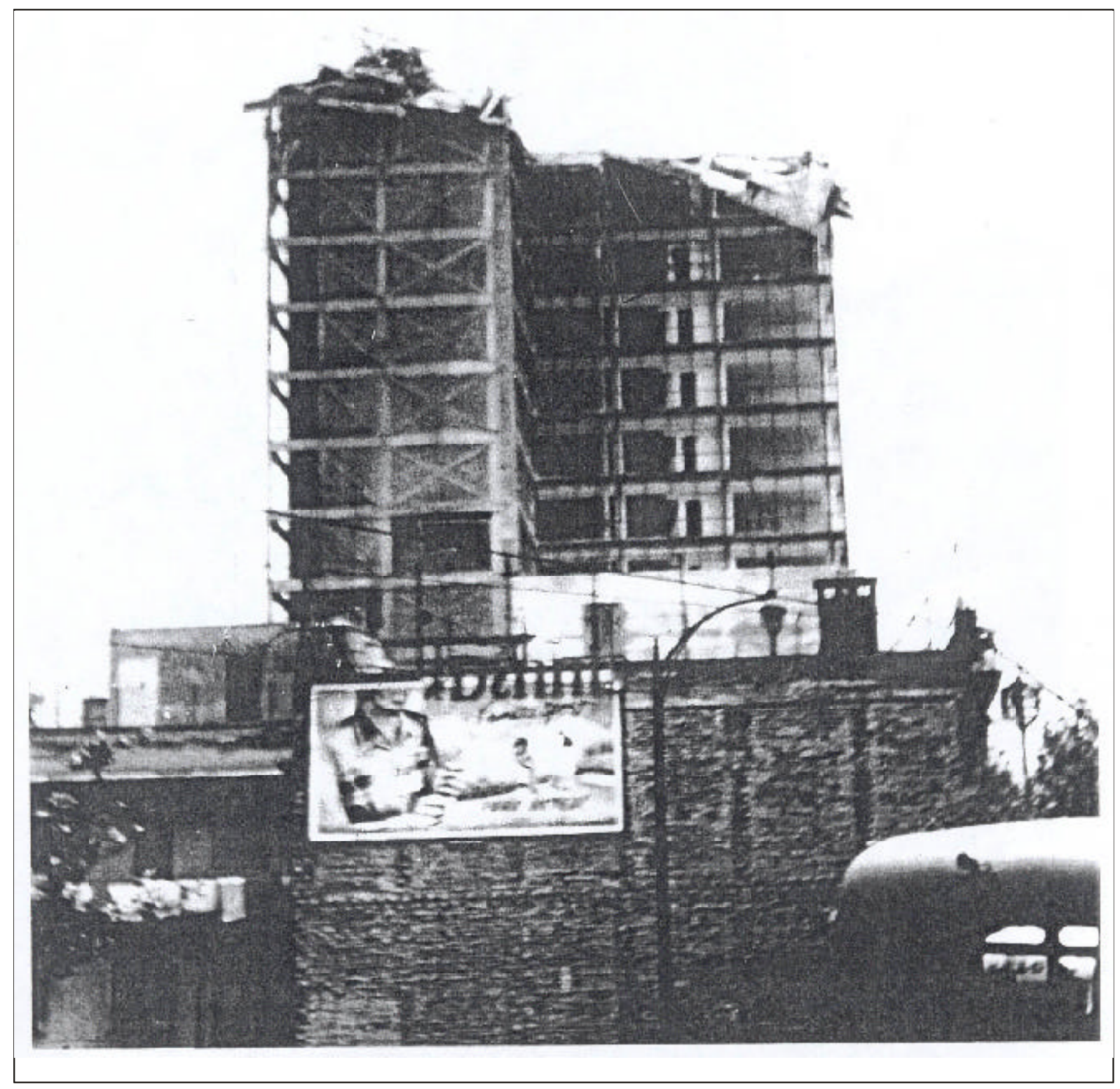

Photo 2. "Whip ping effect" in the upper floors because of seismic action 


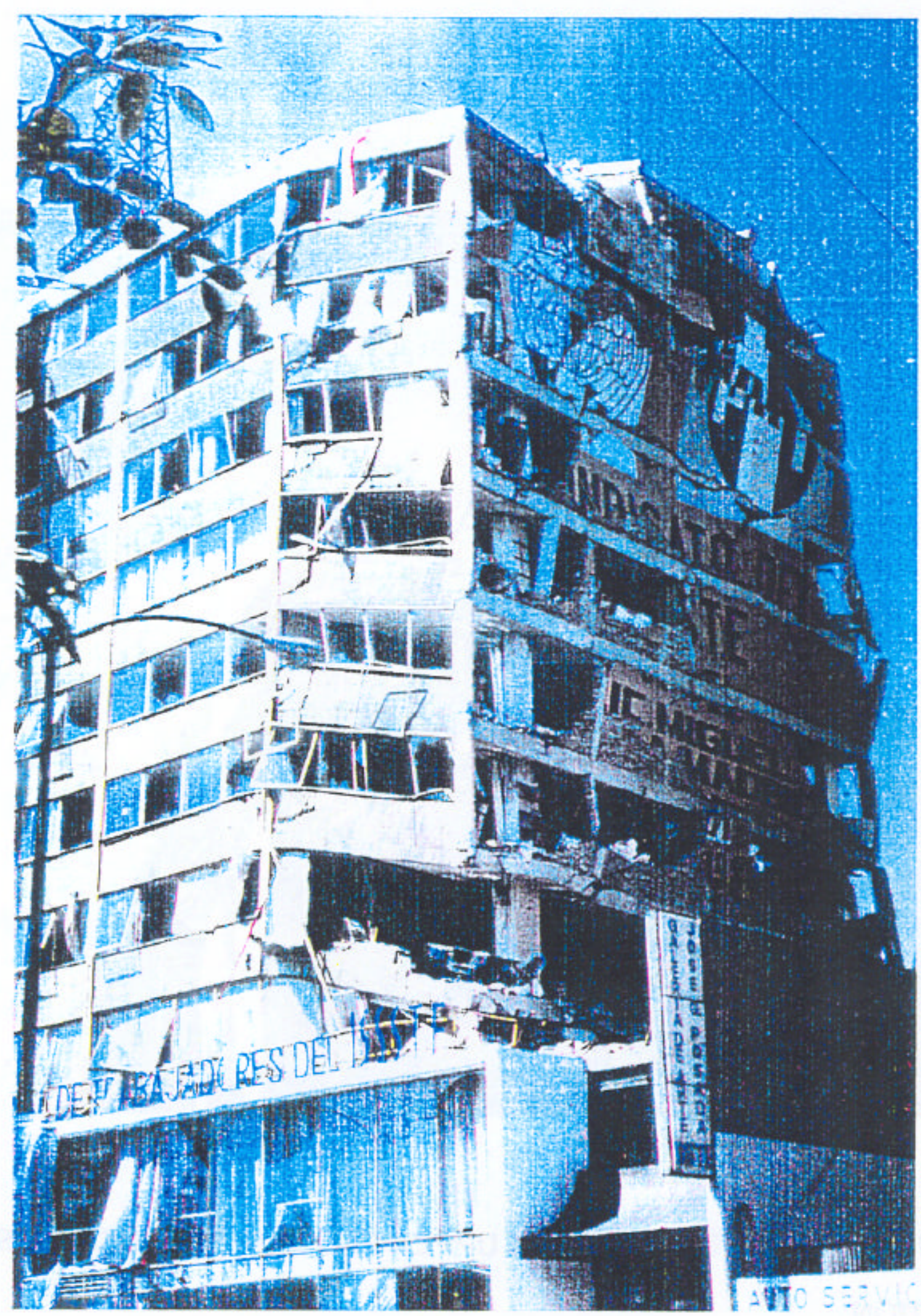

Photo 3. "Whip ping effect" in the upper floors because of seismic action 


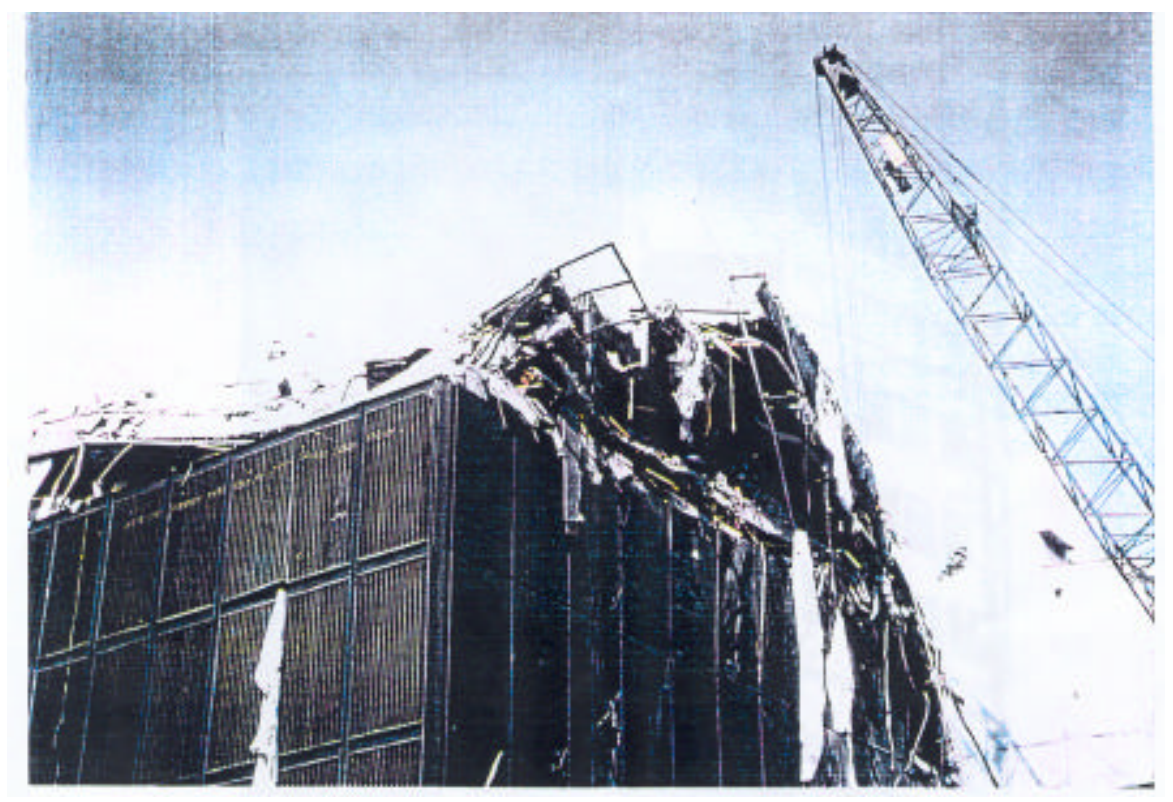

Photo 4. "Whip ping effect" in the upper floors because of seismic action

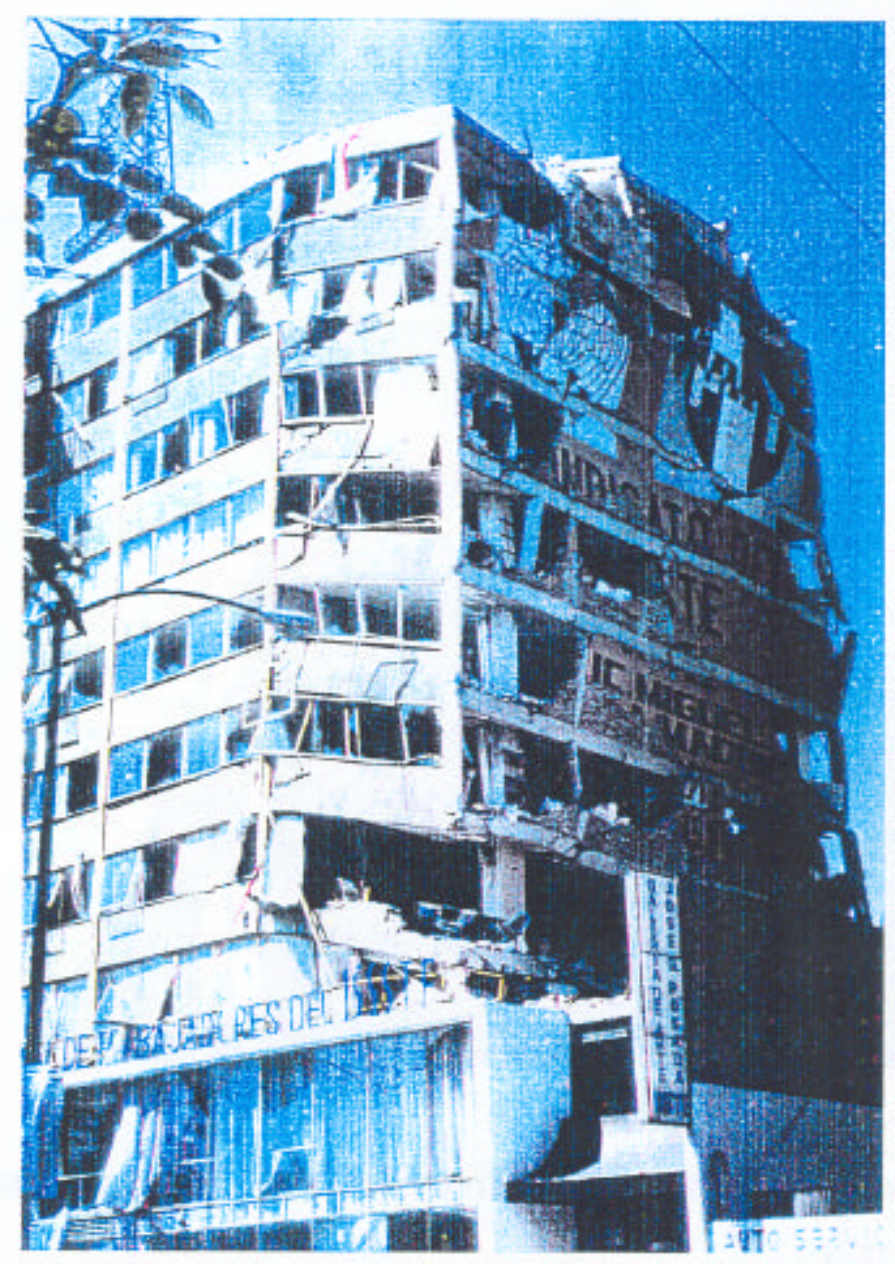

Photo 5. Failure of head-frame (corner) in upper floors because of seismic action 


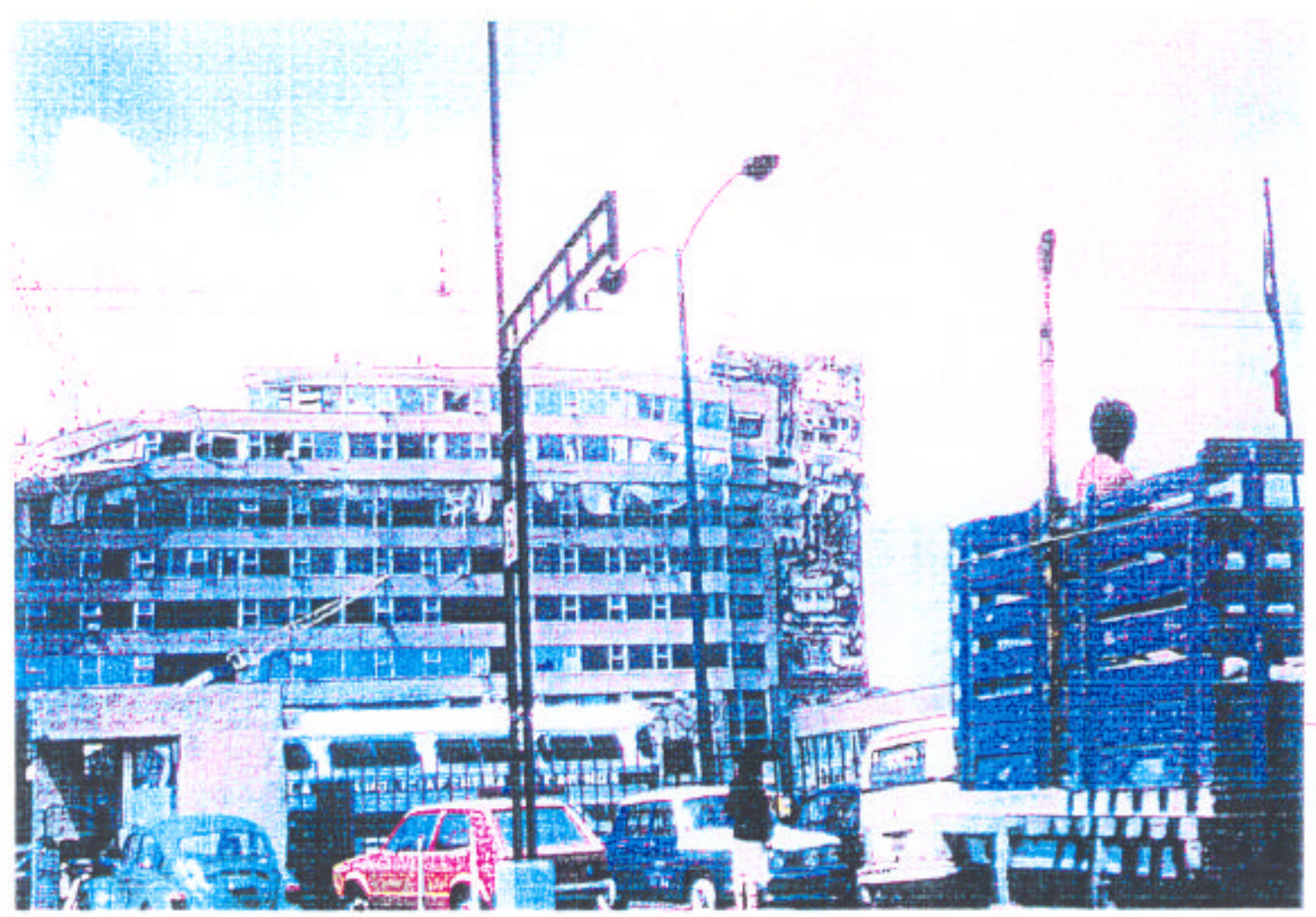

Photo 6. Failure og head-frames in the upper floors because of seismic "torsional whip ping action"

\section{Semblanza del autor}

Leonardo Zeevaert-Wiechers. Obtuvo el título como ingeniero civil en 1939 en la Escuela Nacional de Ingenieros de la UNAM. Estudió el posgrado en el Instituto Tecnológico de Massachussets donde recibió el grado de maestro en ingeniería en 1940. En 1943, inició una estrecha colaboración con el Dr. Karl Terzaghi en una investigación acerca de la estabilidad de las cortinas de corazón hidráulico, construidas en México. A partir de 1940, cuando terminó su maestría en el Instituto Tecnológico de Massachussets, se dedicó a trabajar en problemas específicos de mecánica de suelos y en 1947, ingresó a la Universidad de Illi nois donde terminó en 1949, obteniendo el grado de doctor en filosofía de ingeniería (Ph.D) en ese mismo año. Ha recibido numerosos reconocimientos, entre ellos, la Medalla de Oro Profesional, otorgada por el Instituto Americano de Arquitectos, Diploma a la Innovación Tecnológica, la designación como Profesor Emérito en la UNAM y miembro de la Academia Nacional de Ingeniería de EUA, entre otros. El buen comportamiento de la cimentación y estructura de las obras de ingeniería que ha diseñado, entre ellas la To rre Latinoamericana, en donde introdujo el concepto de flexibilidad controlada en edificios altos y el desarrollo de la "Teoría de la Sismo-Geodinámica", le han valido para su reconocimiento a nivel internacional. Ha escrito más de 195 artículos, una gran cantidad de libros y ha presentado ponencias relacionadas con la mecánica de suelos e ingeniería sísmica para el diseño de las cimentaciones y estructuras de los edificios en las zonas sísmicas. 